\title{
BACE1 is at the crossroad of a toxic vicious cycle involving cellular stress and $\beta$-amyloid production in Alzheimer's disease
}

\author{
Linda Chami ${ }^{1,2,3}$ and Frédéric Checler ${ }^{1,2,3^{*}}$
}

\begin{abstract}
Alzheimer's disease (AD) is a complex age-related pathology, the etiology of which has not been firmly delineated. Among various histological stigmata, AD-affected brains display several cellular dysfunctions reflecting enhanced oxidative stress, inflammation process and calcium homeostasis disturbance. Most of these alterations are directly or indirectly linked to amyloid $\beta$-peptides (A $\beta$ ), the production, molecular nature and biophysical properties of which likely conditions the degenerative process. It is particularly noticeable that, in a reverse control process, the above-described cellular dysfunctions alter A $\beta$ peptides levels. $\beta$-secretase $\beta$ APP-cleaving enzyme 1 (BACE1) is a key molecular contributor of this cross-talk. This enzyme is responsible for the primary cleavage generating the $\mathrm{N}$-terminus of "full length" A $\beta$ peptides and is also transcriptionally induced by several cellular stresses. This review summarizes data linking brain insults to AD-like pathology and documents the key role of BACE1 at the cross-road of a vicious cycle contributing to $A \beta$ production.
\end{abstract}

Keywords: Alzheimer's disease, BACE1, Inflammation, Oxidative stress, Calcium

\section{The amyloid beta peptides}

Alzheimer's disease patients show progressive and irreversible memory and cognitive impairments, ultimately leading to the loss of their autonomy. This disabling disease is the first cause of dementia in the elderly population. Histopathological lesions include extracellular senile plaques mainly composed of a set of hydrophobic peptides referred to as amyloid $\beta$-peptides (A $\beta$ ), intracellular neurofibrillary tangles due to abnormally phosphorylated tau protein, local inflammation characterized by activated microglia and astrocytes, and neuronal loss [1]. Several risk factors such as aging, brain insults (stroke, traumatic injury), cardiovascular diseases (hypertension), or metabolic diseases (diabetes mellitus, hypercholesterolemia, obesity) [2] as well as genetic risk factors [3] have been identified but the etiology of the disease is far from being fully understood.

\footnotetext{
* Correspondence: checler@ipmc.cnrs.fr

${ }^{1}$ Institut de Pharmacologie Moléculaire et Cellulaire, UMR7275 CNRS/UNSA, 06560 Valbonne, France

${ }^{2}$ Team labelized Fondation pour la Recherche Médicale, 660 route des Lucioles, Sophia Antipolis, 06560 Valbonne, France

Full list of author information is available at the end of the article
}

$\mathrm{A} \beta$ peptides composing the core of senile plaques are mainly produced by neuronal cells [4] and are proteolytically derived from a transmembrane precursor protein, the $\beta$ amyloid precursor protein ( $\beta$ APP). $\beta$ APP undergoes subsequent cleavages by $\beta$ - and $\gamma$-secretases that ultimately generate $A \beta$ peptides. An alternative and prominent processing of $\beta$ APP by $\alpha$-secretase takes place in the middle of the $A \beta$ domain of $\beta A P P$ and is regarded as a physiological non-amyloidogenic pathway [5].

Even if the etiology of AD is still a matter of discussion, it is generally admitted that, if not acting as the initial trigger, $\mathrm{A} \beta$ peptides at least contribute to $\mathrm{AD}$ pathogenesis [6]. This reasonable statement is supported by genetic data. Thus, mutations responsible for early onset and aggressive $\mathrm{AD}$ cases affect three genes encoding proteins involved in $\mathrm{A} \beta$ production, namely $\beta \mathrm{APP}$, and presenilin 1 and 2 [7]. All these mutations modulate the endogenous levels or nature of $A \beta$ peptides [5]. More recently, an additional genetic clue came from the observation that a novel mutation on $\beta$ APP that partly prevents its $\beta$-secretasemediated cleavage and thereby reducing $A \beta$ load, indeed protected bearers from $\mathrm{AD}$ in an Icelanders cohort [8].

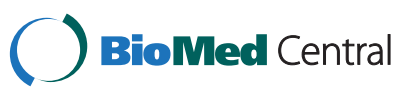


Various $A \beta$ peptides species are found in senile deposits as well as inside cells. Their nature and length can vary drastically. Genuine "full length" A $\beta$ peptides, that are $A \beta 1-40$ or $A \beta 1-42$, can undergo a variety of secondary proteolytic cleavages including $\mathrm{N}$-terminal truncation and cyclisation $[9,10]$. Moreover, monomeric soluble $A \beta$ peptides could associate to form small soluble aggregates including oligomers and protofibrils. Soluble oligomeric species apparently display higher toxic potential for cells than $A \beta$ monomers $[11,12]$. Therefore, the pathology likely results from modifications of the nature and concentration of $A \beta$ peptides, an alteration of their biophysical properties and aggregated state, and a change in their subcellular production and accumulation that are likely underlying $\mathrm{A} \beta$-associated toxicity.

In sporadic cases of $\mathrm{AD}$, there is no evidence for an up-regulation of $A \beta$ production and it is widely admitted that $A \beta$ accumulation derives from impairment/alteration of its degradation/clearance. Amyloid peptides are mainly degraded enzymatically by neprilysin, but also and, likely to a lesser extent, by insulin degrading enzyme (IDE), endothelin-converting enzyme (ECE), angiotensin-converting enzyme (ACE), and plasmin [13]. Neprilysin mRNA and proteins are reduced in brain areas vulnerable to amyloid deposits [14] as is neprilysin activity in AD brains [15].

$\beta A P P$ and its proteolytic fragments are involved in complex networks and several feedback loops have been suggested [16]. Furthermore A $\beta$ would be able to induce its own production. Thus, the treatment of human NT2N neurons with $A \beta$ peptide increased $\beta$ APP processing and production of $A \beta$ peptides [17]. A $\beta$ peptide can activate its own production by binding to the promoters of $\beta A P P$ and BACE1, as $A \beta$ has been recently shown to display transcription factor properties [18,19]. Furthermore, more related to the purpose of the present review, A $\beta$ can also indirectly activate its production by generating various cellular dysfunctions, as detailed below.

\section{The $\boldsymbol{\beta}$-secretase $\beta$ APP-cleaving enzyme 1}

BACE1 (Asp2, memapsin 2), a single transmembrane aspartyl-protease, was identified in 1999 as the major $\beta$-secretase-like protein [20-24]. Thus, brains and primary cortical cultures derived from BACE1 knock-out mice [25-27] are devoid of $\beta$-secretase-like activity and do not produce $\mathrm{A} \beta$. BACE1 is mainly expressed in neurons and in reactive astrocytes [4], in the Golgi apparatus and endosomes of cells, where amyloid peptides are mainly produced [28]. $\beta$-cleavage of $\beta$ APP is the rate-limiting step in $A \beta$ generation [28] and therefore corresponds to an interesting therapeutic target for a strategy aimed at reducing $A \beta$ production. BACE1 is not fully selective for $\beta A P P$ and other substrates have been identified, suggesting an additional role of BACE1 in immunity or sodium channels function [29]. BACE1 knockout mice are viable and fertile [25] but recent data indicate that these mice could harbor axon hypomyelination [30,31], schizophrenia-like [32] and epileptic-like [33] behaviors.

Environmental [34,35] and cellular [36] stresses induce the expression of BACE1. BACE1 promoter harbors functional binding sites for numerous transcription factors including specificity protein 1 (Sp1; [37]), Yin Yang 1 (YY1; [38]), the peroxisome proliferator-activated receptor $\gamma$ (PPAR $\gamma$ [39]), the nuclear factor-kB (NF-kB; [40,41]), the hypoxia-inducible factor 1 (HIF-1; [42]), and signal transducer and activator of transcription 3 (STAT3; [43]). BACE1 activity increases with age [44] and pathology. In AD brains, BACE1 is elevated in regions that develop amyloid plaques and more particularly, in neurons surrounding amyloid plaques $[41,45,46]$. The purpose of this review is to describe transcriptional regulations of BACE1. BACE1 regulation by translational modification, maturation and trafficking will not be treated as they have been nicely reviewed elsewhere [29,47-49].

As stated above, BACE1 is a stress-induced protease. Oxidative stress, inflammation, calcium homeostasis disturbance, hypoxia, ischemia and trauma conditions that occur in $\mathrm{AD}$ activate BACE1 (see below). The activation of BACE1 due to transcriptional deregulation could contribute and possibly accelerate AD pathology by increasing $\mathrm{A} \beta$ production. As $\mathrm{A} \beta 42$ peptide can activate BACE1, [50-53], a positive regulatory loop setting a vicious cycle can be delineated and is described in details below.

\section{Oxidative stress}

\section{Oxidative stress in AD}

Reactive oxygen species (ROS) and reactive nitrogen species are normal products of cell metabolism. Their concentration is balanced by antioxidant factors and is associated to either beneficial or deleterious effects. Low to moderate free radicals concentrations are part of the physiological cellular signaling system and defense mechanisms against infection agents. Conversely, excessive oxidant conditions trigger oxidative stress that turns out to be toxic for cells by damaging lipids, proteins or nucleic acids, ultimately leading to cell death [54]. Oxidative damage further impairs the antioxidant defense and maintains oxidative burden in the cells [2,54].

Lifespan accumulation of free radicals results in ageassociated oxidative stress, the damages of which cause cellular and organism senescence $[2,55]$. Oxidative stress is associated to $\mathrm{AD}$ as an early event [56-58]. Oxidative stress contributes to $\mathrm{AD}$; various mechanisms have been identified [59], such as the oxidative inactivation of the peptidyl-prolyl cis/trans isomerase 1 (Pin1) that affects its regulation of $\beta A P P$ production and tau dephosphorylation [60]. Interestingly, amyloid deposits and neurofibrillary 
tangles have been postulated to be part of antioxidant strategies developed by the organism in response to agerelated increase in oxidative stress (reviewed by $[54,61]$ ).

\section{$A \beta$ generates oxidative stress}

$A \beta$ peptides trigger oxidative stress in vitro and in vivo (reviewed by [59]). On the one hand, $A \beta$ induces ROS generation, with a possible contribution of metal ions. Copper and iron are present in amyloid deposits and their reduction by $A \beta$ produces ROS. The more powerful are the $A \beta$ species considered as the more toxic. Thus, $A \beta 1$ 42 had greater iron and copper reduction potential than $\mathrm{A} \beta 1-40$ in vitro $[62,63]$, and prefibrillar and oligomeric forms of $A \beta 1-42$ induced higher oxidative stress than fibrillar A $\beta 1-42$ in neuronal cells [50]. On the other hand, $A \beta$ peptides contribute to oxidative stress by impairing the cellular antioxidant systems. Thus continuous ventricular $A \beta$ infusion reduced the immunoreactivity of the Mn-superoxide dismutase (Mn-SOD) and proteins of the glutathione antioxidant system in rats [64].

\section{Oxidative stress activates BACE1}

BACE1 activity is positively correlated to oxidative stress markers in AD brains [65]. Treatment of cells with various oxidants increases BACE1 transcription, expression and activity [66,67]. Oxidative stress regulates the $\gamma$-secretase activity as well [51], and treated cells produce more $A \beta$ peptides $[68,69]$.

The JNK pathway is activated in response to oxidative stress, inflammatory cytokines and excitotoxic stimuli; then activated JNK positively regulates inflammation and apoptosis [70]. JNK is activated by $\mathrm{A} \beta$ in neuronal cultures $[71,72]$ and high levels of activated JNK have been reported in degenerating neurons of human AD brains [73] or transgenic mice [72]. JNK pathway also contributes to $\mathrm{A} \beta$ toxicity in vitro $[71,74]$ and production. Thus JNK gene manipulation or pharmacological blockade prevented oxidative stress-induced upregulation of BACE1 in mouse fibroblasts as well as in mice [51]. Therefore, the c-Jun N-terminal kinases (JNK) pathway is involved in BACE1 regulation by oxidative stress.

\section{$A \beta$ peptides regulate BACE1 by generating oxidative stress}

As detailed before, $A \beta$ induces oxidative stress and the latter activates BACE1. Hence $A \beta$ indirectly regulates BACE1 by generating oxidative stress. The JNK pathway and its major transcription factor activator protein1 (AP-1) are involved in this regulation. Guglielmotto and collaborators demonstrated that pharmacological inhibition and gene depletion or mutation of JNK or downstream proteins abolished A $\beta 42$ control of BACE1 activation in murine fibroblasts [72]. Therefore, by inducing oxidative stress and activation of BACE1, A $\beta$ regulates its own production (Figure 1).

\section{Inflammation}

\section{Inflammation in AD}

In response to an injurious stimulus, the organism settles inflammation until the physiological homeostasis is restored. In the central nervous system, microglia is the major actor of inflammation. Resting glial cells become motile when activated and surrounds damaged cells, clearoff cellular debris and release inflammatory agents such as cytokines, chemokines, complement factors, and free radical species [75]. These signals activate astrocytes that undergo morphological and functional changes, and thus participate to the inflammatory process [75]. Neurons contribute to microglial activation by production of proinflammatory cytokines and complement proteins [76].

Neuroinflammation accompanies normal aging. Aging rodents harbor increased activated microglia and astrocytes together with an increase of pro-inflammatory cytokines or a decrease of anti-inflammatory cytokines [77]. Local and chronic neuroinflammation is a constant feature of $\mathrm{AD}$, and is characterized by activated microglia and astrocytes surrounding amyloid plaques and neurofibrillary tangles [78]. Accordingly, elevated levels of cytokines are measured in AD brains [79]. Inflammation can exert both neuroprotective and neurotoxic functions that are directly linked to the duration of the

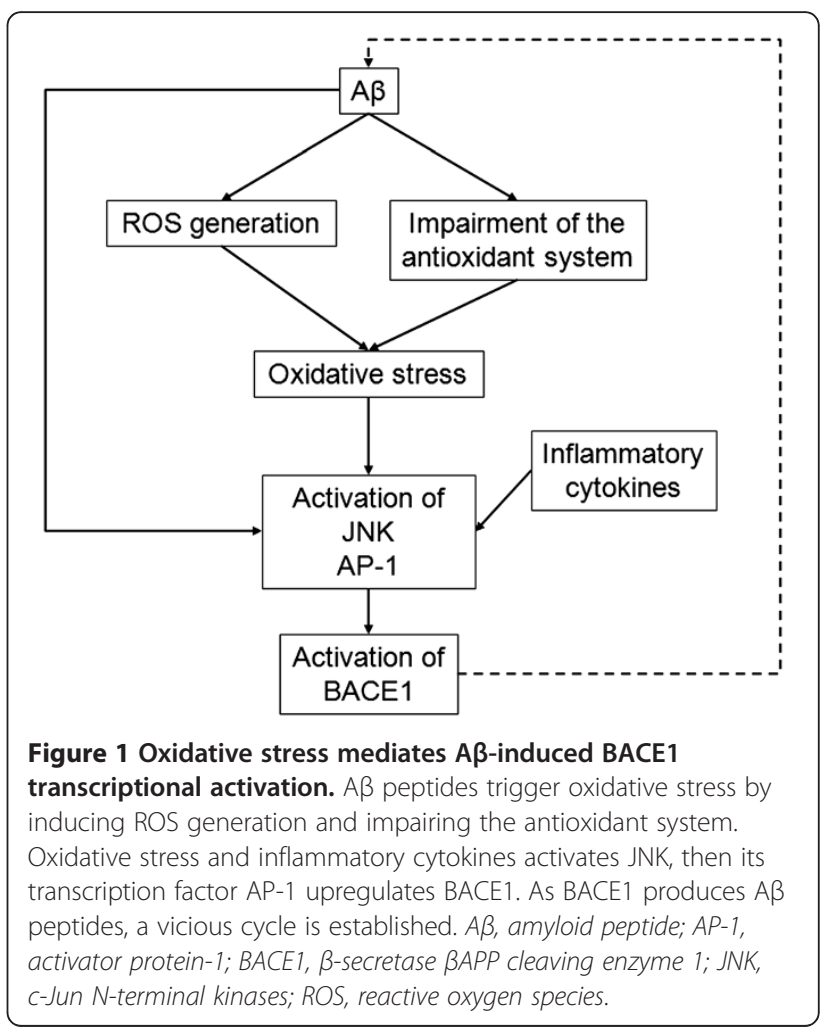


inflammatory process. Acute inflammation is considered to be beneficial by contributing to restore the physiological integrity of tissues. Activated glial cells are thus beneficial since they clear $A \beta$ by phagocytosis and degradation $[80,81]$. On the other hand, sustained inflammation observed in $\mathrm{AD}$ brains, probably in response to continuous accumulation of $\mathrm{A} \beta$ peptides and cellular debris, can be toxic to neurons since inflammatory mediators such as ROS, cytokines and chemokines could directly take part to neurite retraction, neuronal dysfunction and neuronal death $[80,82]$. The metabolites released by activated microglia add to the dual effect of inflammation, as they can be neurotoxic, antioxidant, pro- or anti-inflammatory. The role of inflammation in $\mathrm{AD}$ is therefore the resultant of various cellular and molecular events.

\section{$A \beta$ peptides are pro-inflammatory}

$A \beta$ treatment induces an activation of microglial and astrocytic cells, leading to the release of inflammatory factors $[75,83,84]$. A $\beta$ activate glial cells by direct binding to microglial cell surface receptors [85], such as the receptor for advanced glycation end products (RAGE, [86]), by direct activation of the complement system [87], or by generating oxidative stress [88].

The transcription factor NF- $\mathrm{kB}$ is activated in response to various stresses [88]. NF- $\mathrm{kB}$ is induced by inflammationand oxidative stress-linked conditions such as release of cytokines [88] and ROS [89], as well as ischemia [90] or traumatic brain injury [91] in rats. NF- $\mathrm{kB}$ has a dual role in inflammation, since it is associated to pro-inflammatory or anti-inflammatory genes induction during the onset or the management of inflammation, respectively [92].

$\mathrm{A} \beta$ peptides activate NF- $\mathrm{kB}$ in neurons and astrocytes $[17,93,94]$. The lowest $A \beta$ concentrations were the more efficient to activate NF- $\kappa B[93,94]$. NF- $\kappa B$ activation has been reported in human cortex areas affected by the pathology, particularly in cells surrounding senile plaques [41,93-95]. The role of NF- $\kappa B$ activation remains unclear. Several works suggested a protective cellular response to $A \beta$-induced cell death $[94,96]$. However other studies indicated that NF- $\mathrm{KB}$ could contribute to $\mathrm{A} \beta$-associated toxicity, as inhibition of NF- $\mathrm{KB}$ reduced A $\beta$-induced neuronal death $[17,97]$.

\section{Inflammation activates BACE1}

The well-known inflammation inducer lipopolysaccharide (LPS) increases $\beta$ APP expression and processing in Swedish- $\beta$ APP transgenic mice [98]. LPS and inflammation activate the transcription factor NF- $\mathrm{KB}$, for which BACE1 promoter harbors a highly conserved binding site [99] that is functional $[40,41]$. NF- $\mathrm{kB}$ physiologically represses $\mathrm{BACE} 1$ transcription in vitro $[40,100]$, therefore limiting $A \beta$ production.
However inflammatory conditions could favor $A \beta$ production by switching the NF-kB inhibition of BACE1 transcription towards an activation process as suggested by many studies. Thus NF-kB activates BACE1 promoter, expression and enzymatic activity in activated astrocytes and $A \beta$-exposed or $A \beta$-overproducing cells, leading to increased $A \beta$ production $[40,41,52,100]$. In vivo, the modulation of NF- $\mathrm{kB}$ activity by non-steroidal anti-inflammatory drugs [101], natural compounds $[102,103]$ or by targeting upstream receptors of the NF$\mathrm{KB}$ activation pathway $[58,104]$, all affect $\mathrm{A} \beta$ production. In transgenic mice NF- $\mathrm{kB}$ activates $\beta$ APP levels [103], BACE1 promoter activity [104], expression [102,105] and enzymatic activity $[102,103]$ as well as $\gamma$-secretase activity [103] and $A \beta$ production [101-103].

NF-kB-dependent regulation of BACE1 is therefore ambivalent, since NF- $\mathrm{kB}$ would physiologically repress BACE1 transcription, but would convert into an activator of BACE1 in cells exposed to an $A \beta$ overload $[40,100]$. This could be explained by the activation of different NF$\kappa B$ heterodimers yielded in a stimulus-dependent manner [40] even if this remains to be definitely established.

Other mediators of inflammation contribute to the regulation of BACE1. PPARY are nuclear receptors that inhibit pro-inflammatory gene expression such as NF$\kappa \mathrm{B}$-regulated genes, and are targeted by some nonsteroidal anti-inflammatory drugs (NSAID, [106]). PPAR $\gamma$ inhibits BACE1 transcription through a functional PPAR response element on BACE1 promoter and interferes with the cytokines-induced $A \beta$ production, as demonstrated in cells and confirmed in transgenic mice and human brains $[39,107,108]$. PPAR $\gamma$ agonists have additional beneficial effects on $A \beta$ peptides production by increasing $\beta A P P$ or BACE1 degradation $[109,110]$.

Prolonged inflammation could favor $\mathrm{A} \beta$ production by activating astrocytes, as demonstrated by various in vitro and in vivo studies. Thus, chronic stress, pro-inflammatory cytokines or A $\beta 42$ itself increase BACE1 levels and activity as well as $\beta A P P$ levels in astrocytes. The transcription factors NF- $\mathrm{kB}, \mathrm{YY} 1$ and STAT1 could account for the stressinduced increase of BACE1 transcription in astrocytes [38,40,111-115] that are observed in the vicinity of amyloid plaques in both aged $\mathrm{Tg} 2576$ mice and AD-affected brains [116]. However a recent study challenges these results by showing a reduced $A \beta$ secretion in response to cytokine stimulation of cultured rat astrocytes, in which the $\beta$-secretase activity would be accounted for by the BACE1 homolog, BACE2 [117].

\section{$A \beta$ peptides regulate their own production by triggering NF-KB-mediated BACE1 activation}

At supraphysiological levels, $A \beta$ induces an upregulation of BACE1 transcriptional activity, protein expression, enzymatic activity, and consequently intracellular accumulation 
and secretion of $A \beta$, by activating NF-kB $[17,40,52,100]$. BACE1 transcription is therefore activated by $A \beta$ and by inflammation. In turn, BACE1 can promote inflammation by the production of two pro-inflammatory agents that are $A \beta$ and the prostaglandin $E 2$, produced by BACE1 cleavage of the membrane-bound prostaglandin E2 synthase-2 [118]. Therefore by inducing inflammation and NF- $\kappa B$ activation, $A \beta$ could act on its own production (Figure 2).

\section{Calcium homeostasis perturbation}

\section{Calcium signaling perturbation in $A D$}

Calcium is a major signaling molecule involved in a variety of neuronal functions, such as neurotransmission, synaptic plasticity, excitotoxicity or apoptosis $[119,120]$. Aging affects calcium sensitivity and homeostasis, thereby triggering neuronal vulnerability and cell death. Oxidative stress is tightly associated to these calcium homeostasis alterations [121,122].

The calcium signaling pathway is altered in AD. Intracellular levels of calcium are increased by a disturbed entry of external calcium, an exacerbated release from the internal storage organelles endoplasmic reticulum and mitochondria, and/or an hypersensitivity of the system $[121,123]$. The disturbed calcium signaling alters long-term potentiation and long-term depression, thus affecting learning and memory. Finally, an overload of calcium can induce the mitochondria to trigger apoptosis and neurodegeneration [121]. The polymorphism of a calcium channel was formerly associated to an

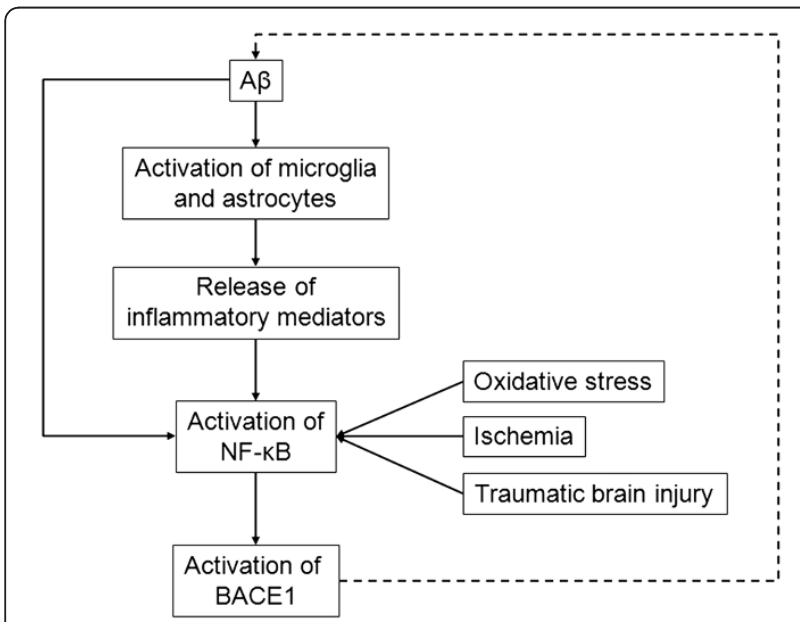

Figure 2 Inflammation mediates $A \beta$-induced BACE1

transcriptional activation. $A \beta$ peptides are pro-inflammatory. They activate microglia and astrocytes that release inflammatory

mediators. Those activate NF-kB, which is also activated by oxidative

stress, ischemia or traumatic brain injury. Pathological activation of

NF-KB activates BACE1 transcription, thus increasing $A \beta$ peptides

levels and feeding a vicious cycle. $A \beta$, amyloid peptide; $B A C E 1$,

$\beta$-secretase $\beta A P P$ cleaving enzyme 1; NF-KB, nuclear factor- $K B$. increased risk of $\mathrm{AD}$. The calcium homeostasis modulator 1 (CALHM1) channel controls intracellular calcium levels and calcium-dependent $\alpha$-secretase-mediated processing of $\beta$ APP [124]. A polymorphism in its gene impairs its physiological functions and favors $A \beta$ overload. Currently, the CALHM1 polymorphism is rather considered as a genetic modifier of age at onset in $\mathrm{AD}$ [125].

\section{$A \beta$ affects cellular calcium homeostasis}

Calcium homeostasis disturbance is part of $A \beta$ neurotoxicity (for reviews see [120-122]). Amyloid peptides increase the level of cytoplasmic calcium through several mechanisms, as suggested by the in vitro experiments described below. $A \beta$ can trigger an extracellular calcium influx by stimulating membrane ion channels or receptors, such as ionotropic glutamate receptors [126]. A $\beta$ could impair the intracellular distribution of calcium by perforating and permeabilizing the membrane to calcium via oxidative stress $[120,127,128]$. Noteworthy, some presenilin mutations responsible for familial $\mathrm{AD}$ and yielding enhanced $A \beta$ levels, impair calcium homeostasis by deregulating internal calcium channels ryanodine receptor [129], inositol 1,4,5-triphosphate (IP3) channel [130] or sarco endoplasmic reticulum calcium ATPase (SERCA; [131]). This agreed well with our recent work showing that the overexpression of both wild-type and Swedishmutated BAPP increased Ryanodine receptors (RyR) expression and enhanced RyR-mediated ER Ca2+ release in neuroblastoma cells as well as in transgenic mice [132]. Altering presenilin functions has an impact on calcium homeostasis by an additional mechanism. Concomitant to the generation of $A \beta$, the $\gamma$-secretase complex releases the $\beta$ APP intracellular domain (AICD) which acts as a transcription factor [133] involved in the transactivation of genes related to AD $[134,135]$. Similarly, AICD is involved in calcium signaling [136] or homeostasis in different cell culture models [137].

\section{Calcium disturbance activates BACE1}

Calcium dysregulation promotes tau phosphorylation and $A \beta$ accumulation in neuronal cells [138-140]. Calpain is an intracellular cystein protease regulated by calcium and abnormally activated in AD brains [141,142]. In transgenic mice brains, calpain over-activation induces amyloid deposits, tau phosphorylation, activation of astrocytes, synapse loss and cognitive impairment $[141,143]$. Furthermore, $\beta$ APP processing is affected as $\beta$ APP $C$-terminal fragments are decreased following calpain inhibition in these mice [143].

BACE1 upregulation could be mediated by cyclindependent kinase 5 (cdk5), which is regulated by calpain [144]. Cdk5 activates BACE1 promoter by binding of its target STAT3, therefore increasing BACE1 activity, 
$\mathrm{A} \beta 1-40$ and $\mathrm{A} \beta 1-42$ production in transgenic mice [43]. Another calcium-dependent transcription factor regulates BACE1 transcription. The calcium-activated nuclear factor of activated T-cells 1 (NFAT1), which is abnormally activated in transgenic mice brain [145], translocates to the nucleus, binds to BACE1 promoter, activates its transcription and increases $A \beta$ generation, as demonstrated in vitro [145].

Many evidences thus imply a calcium-dependent activation of BACE1. However, two in vitro studies suggest that the regulation of $A \beta$ production by calcium would be more complex. Hayley and collaborators who demonstrated a physical interaction between calcium and BACE1 reported on an activation of BACE1 activity at low calcium concentration, and conversely, a progressive reduction of BACE1 activity when increasing calcium concentration [146]. Similar results were obtained on $A \beta$ production using thapsigargin, a pharmacological raiser of cytoplasmic calcium levels [147].

\section{$A \beta$ peptides regulate $B A C E 1$ via calcium-dependent pathways}

As detailed above, impaired calcium homeostasis activates BACE1 via activation of NFAT1 and the calpain/ cdk5/STAT3 pathway. By altering calcium signaling, $A \beta$ regulates BACE1 through both pathways. A $\beta$ treatment of cultured neurons activated calpain, cdk5, NFAT1
$[145,148]$ and increased BACE1 expression $[143,145]$ that was reduced by calpain inhibition [143] or calcineurinmediated NFAT1 inhibition [145]. Therefore calcium is another intermediate by which $\mathrm{A} \beta$ upregulates BACE1, and thus its own production (Figure 3 ).

\section{Advanced glycation end (AGE) products AGEs in AD}

AGEs are normal products of cellular metabolism. They result from irreversible post-translational modifications of proteins on which monosaccharides are grafted by non-enzymatic mechanisms. By generating proteaseresistant peptides and proteins, this reaction leads to protein deposition and amyloidosis [149]. AGEs accumulate in aged tissue and contribute to the age-related deterioration of cellular functions [150]. AGE production can be enhanced in pathological contexts such as diabetes mellitus-associated hyperglycemia, inflammation, and hypoxia $[149,151]$. AGEs pathogenicity is linked to the concomitant oxidative stress generated during their formation, to their interaction with its receptor RAGE [152], or by the accumulation of non-degradable proteins $[149,151]$. Furthermore, AGEs binding to RAGE intensifies inflammation by activation of NF- $\mathrm{KB}$ and by release of pro-inflammatory cytokines [153,154]. In turn, NF-кB transactivates RAGE promoter [155]. Finally, AGEs compete with other physiological ligands interacting with

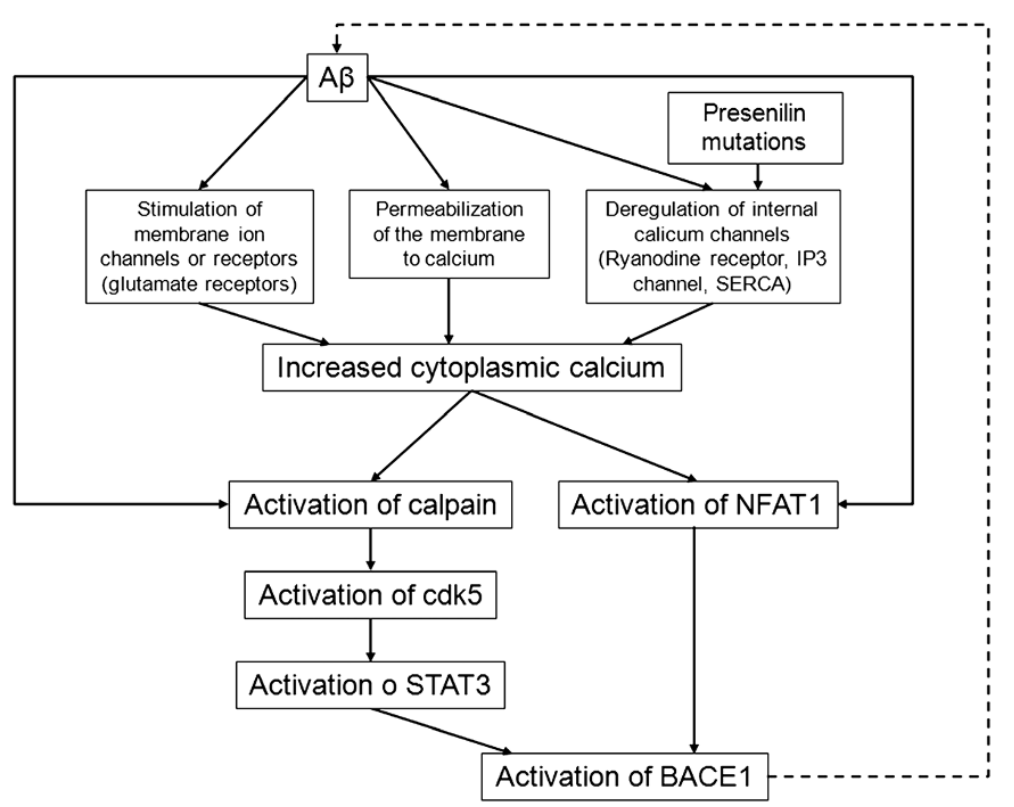

Figure 3 Disturbed calcium homeostasis mediates $\mathbf{A} \beta$-induced BACE1 transcriptional activation. A $\beta$ peptides increase cytoplasmic calcium by at least three mechanisms: stimulation of membrane ion channels or receptors; permeabilization of the membrane; and deregulation of internal calcium channels. Presenilins mutations contribute to the latter. Increased calcium then activates the calpain/cdk5/STAT3 pathway and NFAT1. The transcription factors STAT3 and NFAT1 upregulate BACE1, which then produces more A $\beta$ peptides and a positive feedback mechanism is set up. $A \beta$, amyloid peptide; BACE1, $\beta$-secretase $\beta A P P$ cleaving enzyme 1; cdk5, cyclin-dependent kinase 5; IP3, inositol 1,4,5-triphosphate; NFAT1, nuclear factor of activated T-cells 1; SERCA, sarco endoplasmic reticulum calcium ATPase; STAT, signal transducer and activator of transcription. 
RAGE, such as growth or differentiation factors $[149,151]$.

Cerebral levels of AGEs are increased in human AD brains, especially in neurofibrillary tangles and amyloid deposits [156-159]. Tau and $A \beta$ peptides are indeed substrates for glycation, which contributes to their pathogenicity. Thus in vitro studies showed that tau glycation impairs its ability to bind to tubulin [160], and AGEs favor $A \beta$ peptides aggregation $[157,161]$.

\section{$A \beta$ modulates the $A G E / R A G E$ signaling cascade}

$A \beta$ peptides that can be considered as AGEs, bind to RAGE [86] and upregulate this receptor through the cytokine macrophage colony-stimulating factor (M-CSF). This amplifies RAGE sensitivity for $A \beta$ stimulation and probably subsequent pro-inflammatory conditions settled by the microglia [162]. Arancio and collaborators highlighted the contribution of RAGE to AD phenotype. Transgenic mice overexpressing mutant $\beta A P P$ and RAGE exhibited earlier cognitive abnormalities and altered synaptic function, along with an increase in NF- $\mathrm{kB}$ activation and amyloid deposits-associated reactive microglia and astrocytes [163].

\section{AGEs and RAGE activate BACE1}

AGEs can influence $A \beta$ generation. AGEs induce $\beta A P P$ expression by generating oxidative stress in $\mathrm{SH}-$ SY5Y cells [164] and in transgenic mice model of AD, RAGE injection increases $A \beta$ accumulation and senile plaques [165]. As mentioned in this review, prooxidant conditions regulate BACE1. Similarly, BACE1 expression and activity are increased by the activation of RAGE in transgenic mice and SH-SY5Y cells [165]. NFAT1 could be involved in this regulation, since AGEs- or A $\beta$-mediated stimulation of RAGE increased cytosolic calcium concentration, NFAT1 activation and binding to BACE1 promoter in SH-SY5Y cells [165]. The NF- $\mathrm{B}$ p pathway seems also involved in RAGEdependent regulation of BACE1. Thus pentosidine and glyceraldehydes-derived pyridinium, two AGEs that are increased in $\mathrm{AD}$ patients brains, upregulate BACE1 expression by binding with RAGE and subsequent activation of NF- $\mathrm{kB}$ in vitro and in vivo [166]. Therefore, RAGE activation by AGEs or A $\beta$ activate BACE1 transcription and thereby, increases $A \beta$ production (Figure 4).

\section{Brain insults}

\section{Traumatic brain injury}

Traumatic brain injury is a risk factor for AD [167]. Post mortem analysis of patients who had traumatic brain injury revealed deposition of $A \beta$ peptides in brain and abnormal distribution in the cerebrospinal fluid $[167,168]$. This was confirmed in transgenic mice

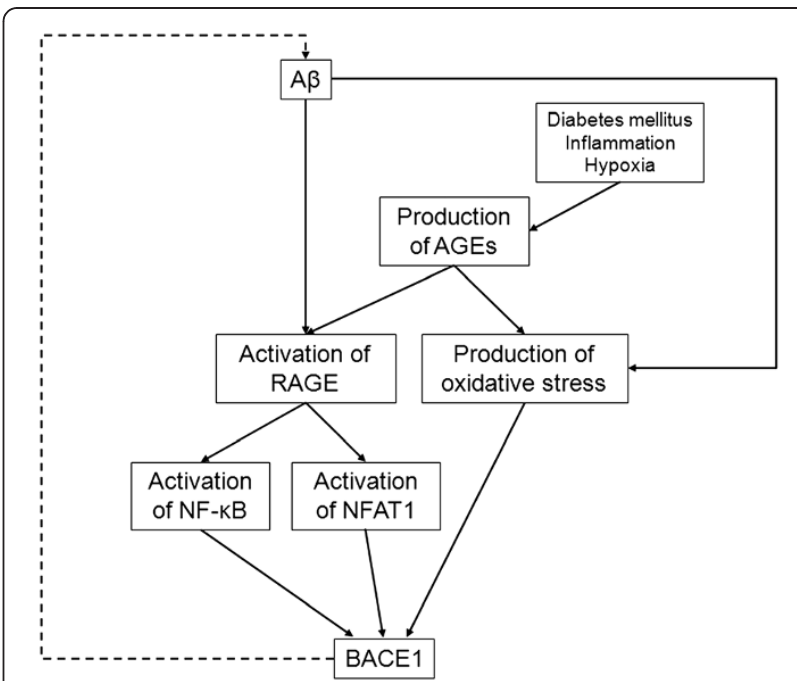

Figure $4 A \beta$ and AGEs activate BACE1 transcription. $A \beta$ peptides activate RAGE. This receptor is also activated by AGEs produced during diabetes mellitus, inflammation or hypoxia. RAGE activation upregulates BACE1 by the activation of the two transcription factors NF-KB and NFAT1. Additionally, AGEs can activate BACE1 by generating oxidative stress. BACE1 contribution to $A \beta$ peptides production then amplifies RAGE activation. $A \beta$, amyloid peptide; $A G E$, advanced glycation end products; BACE1, $\beta$-secretase $\beta A P P$ cleaving enzyme 1; NFAT1, nuclear factor of activated T-cells 1; NF-KB, nuclear factor- $K B$; RAGE, receptor for advanced glycation end products.

model of $\mathrm{AD}$, where repetitive traumatic brain injury triggered $A \beta$ accumulation [169]. Traumatic brain injury is followed by an increase of BACE1 mRNA, protein and activity, as well as an accumulation of $\beta$ APP and presenilin 1 [170-172].

BACE1 activation could be due to oxidative stress and NF- $\mathrm{kB}$ activation following traumatic brain injury $[91,169,173]$, as we previously described that both can upregulate BACE1 (Figure 5). In addition, BACE1 upregulation may result from an impaired degradation. The GGA (Golgi-localizing, $\gamma$-adaptin ear homology domain, ARF-binding) proteins regulate BACE1 trafficking between endosomes and Golgi apparatus [174-176]. Following head injury, activated caspases cleave GGA1 and GGA3, thereby stabilizing BACE1 [177].

BACE1 deletion attenuates brain damages due to traumatic injury. Thus learning impairment and tissue damage are attenuated in BACE1 null mice. BACE1 would contribute to the continuing neuronal damage after the initial injury, where apoptotic and inflammatory pathways are activated [172].

\section{Hypoxia}

Vascular risk factors, like heart disease or stroke leading to hypoperfusion are risk factors for AD $[178,179]$. Hypoperfusion, that is a transient or permanent reduction in cerebral blood flow leading to subsequent hypoxia, 


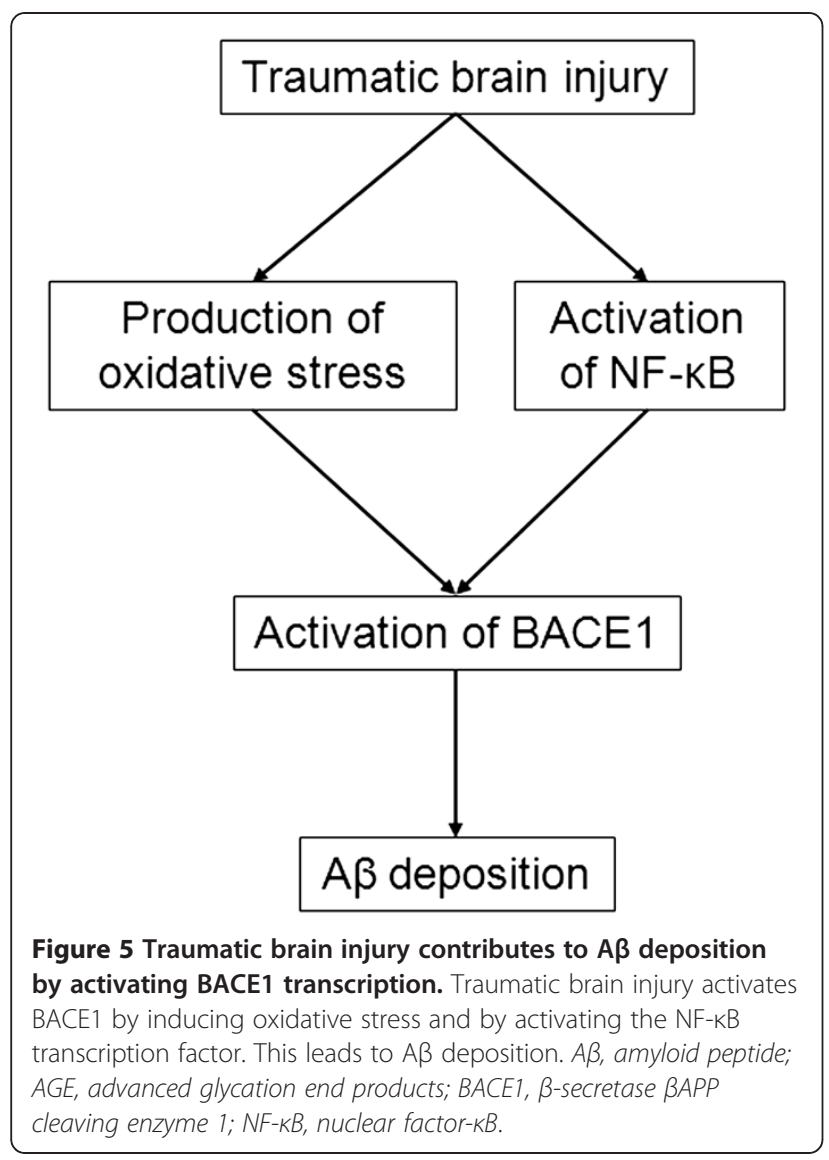

causes a decrease in the important source of energy ATP, a perturbation of ionic gradients, an increase in cytoplasmic calcium concentration, an excitotoxic excess of extracellular glutamate, oxidative stress, and activation of pro-inflammatory pathways, ultimately leading to cell death [180].

In response to hypoxia, BACE1 levels, maturation and activity, as well as $A \beta$ deposition and memory deficits are increased in Swedish mutant APP mice. In this pathological condition, BACE1 transcription is activated by hypoxia-inducible factor (HIF-1), a major transcription factor induced by oxygen reduction [42,181]. Guglielmotto and collaborators [182] proposed a biphasic activation of BACE1 by hypoxia. The early phase would be characterized by the release of ROS from mitochondria and by the activation of the JNK pathway, whereas during the late phase, the HIF1 $\alpha$ transcription factor would take over BACE1 activation. Besides oxidative stress [182], other hypoxia-linked mechanisms could contribute to BACE1 activation, such as the activation of calpain and cdk5 [183-185], or the upregulation of RAGE or NF- $\mathrm{kB}$ by an HIF- $1 \alpha$-dependent transcriptional activation [186-189]. The three mechanisms explaining hypoxia-induced BACE1 upregulation are summarized in Figure 6.

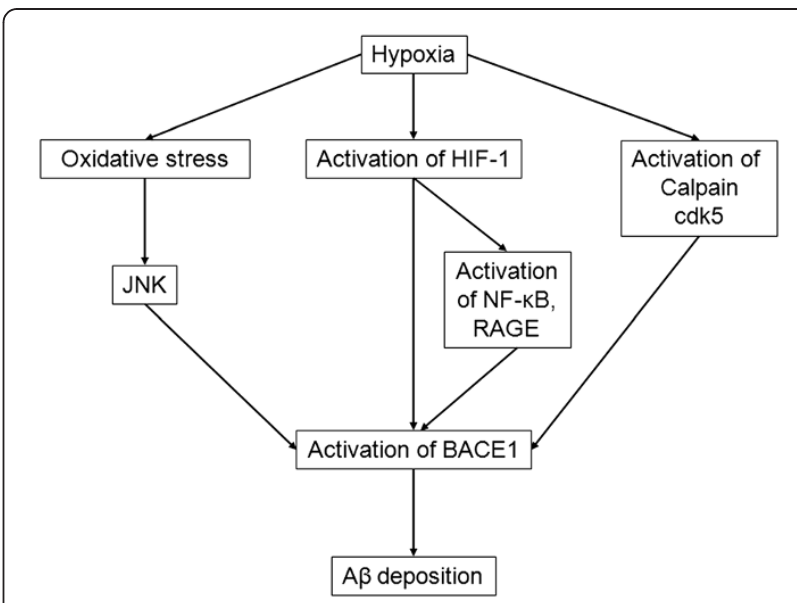

Figure 6 Hypoxia contributes to $A \beta$ deposition by activating BACE1 transcription. Hypoxia activates BACE1 by three distinct mechanisms: generation of oxidative stress and the subsequent activation of the JNK pathway; activation of HIF-1 transcription factor which activates BACE1 promoter directly or indirectly through the activation of NF-KB and RAGE; activation of calpain and cdk5 resulting from increased calcium concentrations. By activating BACE1 transcription, hypoxia thus leads to $A \beta$ deposition. $A \beta$, amyloid peptide; $A G E$, advanced glycation end products; $B A C E 1, \beta$-secretase BAPP cleaving enzyme 1; cdk5, cyclin-dependent kinase 5; HIF-1, hypoxia-inducible factor 1; JNK, c-Jun N-terminal kinases; NF-KB, nuclear factor-KB; RAGE, receptor for advanced glycation end products.

Finally, two additional post-transcriptional mechanisms contribute to elevate BACE1 levels: the phosphorylation of eIF2 $\alpha$ subsequent to energy deprivation that translationally activates BACE1 [190]; reduction of GGA3 levels following ischemia, leading to BACE1 stabilization and increased $\beta$-secretase activity [191].

\section{A $\beta$-linked apoptosis in AD}

$A \beta$ toxicity mediated by oxidative stress, inflammation, disturbed calcium homeostasis and cellular disorder described above, leads to apoptosis. $A \beta$ can activate the extrinsic or the intrinsic apoptotic pathways according to its aggregation state (reviewed in [11]). A $\beta$ can directly induce apoptosis by activating the transcription of the tumor suppressor p53 [192], the expression of which is increased in AD brains [192,193]. Furthermore, by activating $\mathrm{p} 53, \mathrm{~A} \beta$ and AICD can regulate their own production [192,194-196], since p53 has been shown to regulate some of the $\gamma$-secretase complex proteins that are presenilin 1, presenilin 2 and presenilin enhancer 2 (Pen-2) $[195,197,198]$.

\section{Conclusion}

Changes observed in $\mathrm{AD}$ brains are not necessarily causes of the disease, and could be consequences of the pathological process [199]. Most of cellular responses and adaptative processes described in this review as well as $A \beta$ peptides can exert both protective and toxic 
functions according to the cellular context. For $A \beta$ peptides, those include modulating ion channel function [200], neuronal viability [201,202], protection from glutamate and N-methyl-D-aspartic acid excitoxicities [202,203], and reduction of oxidative damage [204-206]. $\mathrm{A} \beta$ excess is considered to have a causative role in $\mathrm{AD}$ pathogenesis, but could be a protective mechanism in response to various stresses $[9,204,207,208]$.

Nevertheless, AD brain cells undergo various stresses mainly caused by oxidative stress, inflammation and calcium homeostasis impairment. Chronic exposition of cells to these age-related perturbations or brain insults maintains supraphysiological BACE1 levels, leading to an increased production of amyloid peptides, particularly significant since their degradation is reduced in AD. Since these peptides in turn contribute to oxidative, inflammatory and disturbed calcium conditions, this overall contributes to feed a morbid vicious cycle described in the Figure 7. According to this scheme, BACE1 activation and accompanying increase in $A \beta$ production play a key role in the amplification of cellular dysfunctions. It should be noted that an interesting recent paper indicates that BACE1 upregulation may contribute to $\mathrm{AD}$ pathogenesis by disturbing synaptic functions, independently of its catalytic role in $\mathrm{A} \beta$ production. Thus, Chen and collaborators showed that BACE1 negatively controls the cAMP/PKA/CREB pathway by interacting

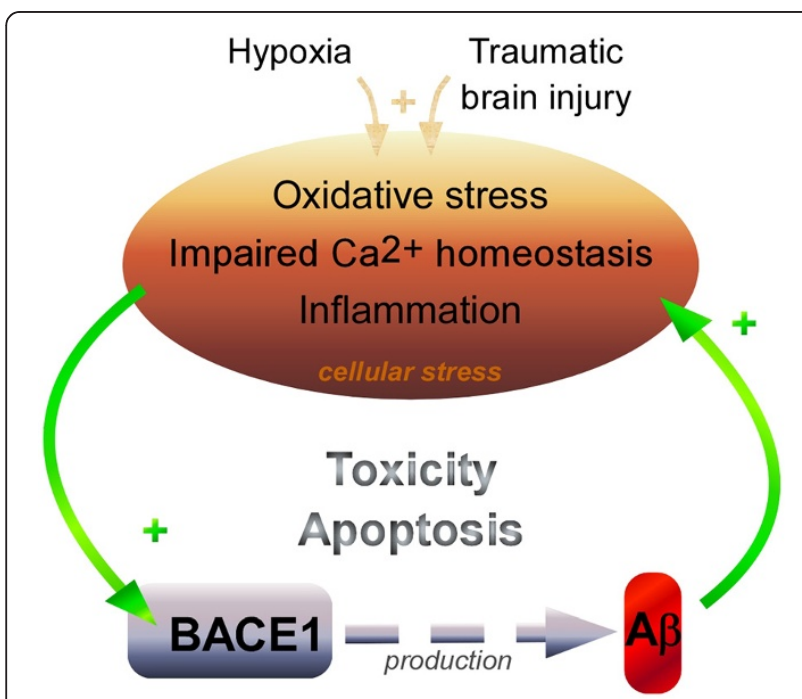

Figure 7 Cellular stress, BACE1 and A $\beta$ production are involved in a toxic vicious cycle in AD. Various cellular dysfunctions including oxidative stress, inflammation and calcium homeostasis disturbance occur in AD-affected brains. These alterations activate the transcription of the stress-induced $\beta$-secretase BACE1 that contributes to $A \beta$ production. Once yielded at supra-physiological levels, $A \beta$ induces cellular stresses that, in turn activate BACE1, therefore setting up a vicious cycle. Such self-maintained toxicity can lead to cellular cell death. Brain insults like hypoxia and traumatic brain injury contribute to this scheme by inducing cellular stress. adenylate cyclase. This regulation was not affected in cells devoid of $A \beta$. The CREB pathway is important for memory functions, and upregulation of BACE1 in mice did affect their learning and memory abilities, in the absence of $\beta$ APP fragments [209].

Since BACE1 contributes to AD pathogenesis and is essential to the cycle described in Figure 7, limiting its activity is an interesting therapeutic strategy. Inhibitors of BACE1 have been developed and improved recently. Some non-peptidic orally available compounds with good pharmacological properties reduced brain $A \beta$ levels in $\mathrm{AD}$ transgenic mice and already are under phase I clinical studies. One of them successfully passed phase I trial and reduced plasma $A \beta$ levels in $A D$ patients (for review, see [210]). However BACE1 inhibition should not be complete to prevent potential side effects (hypomyelination, schizophrenia- and epileptic-like behaviors, hippocampal neurodegeneration [30-33,210]) linked to BACE1-associated proteolysis of other substrates. Different therapeutic strategies aimed at reducing inflammation or oxidative damage in $\mathrm{AD}$ did not prove to be successfull so far $[211,212]$. It is likely that AD treatment may need to target simultaneously distinct components/ pathways to be efficient, and should be used in the early phase of development of the pathology in order to prevent irreversible damages in $\mathrm{AD}$ brains [211].

\section{Abbreviations}

$A \beta$ : amyloid peptide; ACE: angiotensin-converting enzyme; AD: Alzheimer's disease; AGE: advanced glycation end products; AICD: $\beta A P P$ intractellular domain; AP-1: activator protein-1; BACE1: $\beta$-secretase $\beta$ APP cleaving enzyme 1; $\beta$ APP: $\beta$-amyloid precursor protein; CALHM1: calcium homeostasis modulator 1; cdk5: cyclin-dependent kinase 5; ECE: endothelin-convertin enzyme; GGA: golgi-localizing $\gamma$-adaptin ear homology domain, ARF-binding; HIF-1: hypoxia-inducible factor 1; IDE: insulin degrading enzyme; IP3: inositol 1,4,5-triphosphate; JNK: c-Jun N-terminal kinases; LPS: lipopolysaccharide; MCSF: macrophage colony-stimulating factor; NFAT1: nuclear factor of activated T-cells 1; NF-KB: nuclear factor-KB; NSAID: nonsteroidal antiinflammatory drugs; Pen-2: presenilin enhancer 2; Pin-1: peptidyl-prolyl cis/ trans isomerase 1; PPARY: peroxisome proliferator-activated receptor $\gamma$; RAGE: receptor for advanced glycation end products; ROS: reactive oxygen species; SERCA: sarco endoplasmic reticulum calcium ATPase; Sp1: specificity protein 1; STAT: signal transducer and activator of transcription; YY1: Yin Yang 1.

\section{Competing interests}

The authors declare no competing interests.

\section{Authors' contributions}

Manuscript drafted and edited by LC and FC. All authors read and approved the final manuscript.

\section{Acknowledgements}

This work has been supported by the Fondation pour la Recherche Médicale (FRM), by the Conseil Général des Alpes Maritimes, and by the Ministère de l'enseignement supérieur et de la Recherche. This work has been developed and supported through the LABEX (excellence laboratory, program investment for the future) DISTALZ (Development of Innovative Strategies for a Transdisciplinary approach to ALZheimer's disease).

\section{Author details}

${ }^{1}$ Institut de Pharmacologie Moléculaire et Cellulaire, UMR7275 CNRS/UNSA, 06560 Valbonne, France. ${ }^{2}$ Team labelized Fondation pour la Recherche 
Médicale, 660 route des Lucioles, Sophia Antipolis, 06560 Valbonne, France. ${ }^{3}$ LABEX (Laboratory of Excellence), 660 route des Lucioles, Sophia Antipolis, 06560 Valbonne, France.

Received: 13 July 2012 Accepted: 3 October 2012

Published: 5 October 2012

\section{References}

1. Querfurth HW, LaFerla FM: Alzheimer's disease. N Engl J Med 2010, 362:329-344.

2. Kern A, Behl C: The unsolved relationship of brain aging and late-onset Alzheimer disease. Biochim Biophys Acta 2009, 1790:1124-1132.

3. Lambert JC, Amouyel P: Genetics of Alzheimer's disease: new evidences for an old hypothesis? Curr Opin Genet Dev 2011, 21:295-301.

4. Rossner S, Apelt J, Schliebs R, Perez-Polo JR, Bigl V: Neuronal and glial beta-secretase (BACE) protein expression in transgenic Tg2576 mice with amyloid plaque pathology. J Neurosci Res 2001, 64:437-446.

5. Checler F: Processing of the beta-amyloid precursor protein and its regulation in Alzheimer's disease. J Neurochem 1995, 65:1431-1444.

6. Suh $\mathrm{YH}$, Checler F: Amyloid precursor protein, presenilins, and alpha-synuclein: molecular pathogenesis and pharmacological applications in Alzheimer's disease. Pharmacol Rev 2002, 54:469-525.

7. St George-Hyslop PH: Molecular genetics of Alzheimer's disease. Biol Psychiatry 2000, 47:183-199.

8. Jonsson T, Atwal JK, Steinberg S, Snaedal J, Jonsson PV, Bjornsson S, Stefansson H, Sulem P, Gudbjartsson D, Maloney J, et al: A mutation in APP protects against Alzheimer's disease and age-related cognitive decline. Nature 2012, 488:96-9.

9. Sevalle J, Amoyel A, Robert P, Fournie-Zaluski MC, Roques B, Checler F Aminopeptidase $\mathrm{A}$ contributes to the $\mathrm{N}$-terminal truncation of amyloid beta-peptide. J Neurochem 2009, 109:248-256.

10. Schilling S, Zeitschel U, Hoffmann T, Heiser U, Francke M, Kehlen A, Holzer M, Hutter-Paier B, Prokesch M, Windisch M, et al: Glutaminyl cyclase inhibition attenuates pyroglutamate Abeta and Alzheimer's disease-like pathology. Nat Med 2008, 14:1106-1111.

11. Di Carlo M: Beta amyloid peptide: from different aggregation forms to the activation of different biochemical pathways. Eur Biophys J 2010 39:877-888

12. Walsh DM, Klyubin I, Fadeeva JV, Cullen WK, Anwyl R, Wolfe MS, Rowan MJ, Selkoe DJ: Naturally secreted oligomers of amyloid beta protein potently inhibit hippocampal long-term potentiation in vivo. Nature 2002, 416:535-539.

13. Wang DS, Dickson DW, Malter JS: beta-Amyloid degradation and Alzheimer's disease. J Biomed Biotechnol 2006, 2006:58406.

14. Yasojima K, Akiyama H, McGeer EG, McGeer PL: Reduced neprilysin in high plaque areas of Alzheimer brain: a possible relationship to deficient degradation of beta-amyloid peptide. Neurosci Lett 2001, 297:97-100.

15. Wang S, Wang R, Chen L, Bennett DA, Dickson DW, Wang DS: Expression and functional profiling of neprilysin, insulin-degrading enzyme, and endothelin-converting enzyme in prospectively studied elderly and Alzheimer's brain. J Neurochem 2010, 115:47-57

16. Hunter S, Brayne C: Relationships between the amyloid precursor protein and its various proteolytic fragments and neuronal systems. Alzheimers Res Ther 2012, 4:10.

17. Valerio A, Boroni F, Benarese M, Sarnico I, Ghisi V, Bresciani LG, Ferrario M, Borsani G, Spano P, Pizzi M: NF-kappaB pathway: a target for preventing beta-amyloid (Abeta)-induced neuronal damage and Abeta42 production. Eur J Neurosci 2006, 23:1711-1720.

18. Maloney B, Lahiri DK: The Alzheimer's amyloid beta-peptide (Abeta) binds a specific DNA Abeta-interacting domain (AbetaID) in the APP, BACE1, and APOE promoters in a sequence-specific manner: characterizing a new regulatory motif. Gene 2011, 488:1-12.

19. Bailey JA, Maloney B, Ge YW, Lahiri DK: Functional activity of the novel Alzheimer's amyloid beta-peptide interacting domain (AbetaID) in the APP and BACE1 promoter sequences and implications in activating apoptotic genes and in amyloidogenesis. Gene 2011, 488:13-22.

20. Vassar R, Bennett BD, Babu-Khan S, Kahn S, Mendiaz EA, Denis P, Teplow DB, Ross S, Amarante P, Loeloff R, et al: Beta-secretase cleavage of Alzheimer's amyloid precursor protein by the transmembrane aspartic protease BACE. Science 1999, 286:735-741.
21. Sinha S, Anderson JP, Barbour R, Basi GS, Caccavello R, Davis D, Doan M, Dovey HF, Frigon N, Hong J, et al: Purification and cloning of amyloid precursor protein beta-secretase from human brain. Nature 1999, 402:537-540.

22. Yan R, Bienkowski MJ, Shuck ME, Miao H, Tory MC, Pauley AM, Brashier JR, Stratman NC, Mathews WR, Buhl AE, et al: Membrane-anchored aspartyl protease with Alzheimer's disease beta-secretase activity. Nature 1999, 402:533-537.

23. Hussain I, Powell D, Howlett DR, Tew DG, Meek TD, Chapman C, Gloger IS, Murphy KE, Southan CD, Ryan DM, et al: Identification of a novel aspartic protease (Asp 2) as beta-secretase. Mol Cell Neurosci 1999, 14:419-427.

24. Lin X, Koelsch G, Wu S, Downs D, Dashti A, Tang J: Human aspartic protease memapsin 2 cleaves the beta-secretase site of beta-amyloid precursor protein. Proc Natl Acad Sci USA 2000, 97:1456-1460.

25. Roberds SL, Anderson J, Basi G, Bienkowski MJ, Branstetter DG, Chen KS, Freedman SB, Frigon NL, Games D, Hu K, et al: BACE knockout mice are healthy despite lacking the primary beta-secretase activity in brain: implications for Alzheimer's disease therapeutics. Hum Mol Genet 2001, 10:1317-1324

26. Luo Y, Bolon B, Kahn S, Bennett BD, Babu-Khan S, Denis P, Fan W, Kha H, Zhang J, Gong Y, et al: Mice deficient in BACE1, the Alzheimer's beta-secretase, have normal phenotype and abolished beta-amyloid generation. Nat Neurosci 2001, 4:231-232.

27. Cai H, Wang Y, McCarthy D, Wen H, Borchelt DR, Price DL, Wong PC: BACE1 is the major beta-secretase for generation of Abeta peptides by neurons. Nat Neurosci 2001, 4:233-234.

28. Vassar R: The beta-secretase, BACE: a prime drug target for Alzheimer's disease. J Mol Neurosci 2001, 17:157-170.

29. Cole SL, Vassar R: The Alzheimer's disease beta-secretase enzyme, BACE1. Mol Neurodegener 2007, 2:22

30. Hu X, Hicks CW, He W, Wong P, Macklin WB, Trapp BD, Yan R: Bace1 modulates myelination in the central and peripheral nervous system. Nat Neurosci 2006, 9:1520-1525

31. Willem M, Garratt AN, Novak B, Citron M, Kaufmann S, Rittger A, DeStrooper $B$, Saftig P, Birchmeier C, Haass C: Control of peripheral nerve myelination by the beta-secretase BACE1. Science 2006, 314:664-666.

32. Savonenko AV, Melnikova T, Laird FM, Stewart KA, Price DL, Wong PC: Alteration of BACE1-dependent NRG1/ErbB4 signaling and schizophrenia-like phenotypes in BACE1-null mice. Proc Natl Acad Sci USA 2008, 105:5585-5590.

33. Hu X, Zhou X, He W, Yang J, Xiong W, Wong P, Wilson CG, Yan R: BACE deficiency causes altered neuronal activity and neurodegeneration. J Neurosci 2010, 30:8819-8829.

34. Devi L, Alldred MJ, Ginsberg SD, Ohno M: Sex- and brain region-specific acceleration of beta-amyloidogenesis following behavioral stress in a mouse model of Alzheimer's disease. Mol Brain 2010, 3:34

35. Wang Y, Li M, Tang J, Song M, Xu X, Xiong J, Li J, Bai Y: Glucocorticoids facilitate astrocytic amyloid-beta peptide deposition by increasing the expression of APP and BACE1 and decreasing the expression of amyloid-beta-degrading proteases. Endocrinology 2011, 152:2704-2715.

36. Vassar R, Kovacs DM, Yan R, Wong PC: The beta-secretase enzyme BACE in health and Alzheimer's disease: regulation, cell biology, function, and therapeutic potential. J Neurosci 2009, 29:12787-12794.

37. Christensen MA, Zhou W, Qing H, Lehman A, Philipsen S, Song W: Transcriptional regulation of BACE1, the beta-amyloid precursor protein beta-secretase, by Sp1. Mol Cell Biol 2004, 24:865-874.

38. Nowak K, Lange-Dohna C, Zeitschel U, Gunther A, Luscher B, Robitzki A, Perez-Polo R, Rossner S: The transcription factor Yin Yang 1 is an activator of BACE1 expression. J Neurochem 2006, 96:1696-1707.

39. Sastre M, Dewachter I, Rossner S, Bogdanovic N, Rosen E, Borghgraef $P$, Evert BO, Dumitrescu-Ozimek L, Thal DR, Landreth G, et al: Nonsteroidal anti-inflammatory drugs repress beta-secretase gene promoter activity by the activation of PPARgamma. Proc Natl Acad Sci USA 2006, 103:443-448.

40. Bourne KZ, Ferrari DC, Lange-Dohna C, Rossner S, Wood TG, Perez-Polo JR: Differential regulation of BACE1 promoter activity by nuclear factorkappaB in neurons and glia upon exposure to beta-amyloid peptides. J Neurosci Res 2007, 85:1194-1204.

41. Chen $\mathrm{CH}$, Zhou W, Liu S, Deng Y, Cai F, Tone M, Tone Y, Tong Y, Song W: Increased NF-kappaB signalling up-regulates BACE1 expression and its 
therapeutic potential in Alzheimer's disease. Int J Neuropsychopharmacol 2011:1-14.

42. Zhang X, Zhou K, Wang R, Cui J, Lipton SA, Liao FF, Xu H, Zhang YW: Hypoxia-inducible factor 1alpha (HIF-1alpha)-mediated hypoxia increases BACE1 expression and beta-amyloid generation. J Biol Chem 2007, 282:10873-10880.

43. Wen Y, Yu WH, Maloney B, Bailey J, Ma J, Marie I, Maurin T, Wang L, Figueroa $\mathrm{H}$, Herman $\mathrm{M}$, et al: Transcriptional regulation of beta-secretase by $\mathrm{p} 25 / \mathrm{cdk} 5$ leads to enhanced amyloidogenic processing. Neuron 2008 57:680-690.

44. Fukumoto H, Rosene DL, Moss MB, Raju S, Hyman BT, Irizarry MC: Betasecretase activity increases with aging in human, monkey, and mouse brain. Am J Pathol 2004, 164:719-725.

45. Fukumoto $H$, Cheung BS, Hyman BT, Irizarry MC: Beta-secretase protein and activity are increased in the neocortex in Alzheimer disease. Arch Neurol 2002, 59:1381-1389

46. Zhao J, Fu Y, Yasvoina M, Shao P, Hitt B, O'Connor T, Logan S, Maus E, Citron M, Berry R, et al: Beta-site amyloid precursor protein cleaving enzyme 1 levels become elevated in neurons around amyloid plaques: implications for Alzheimer's disease pathogenesis. J Neurosci 2007 27:3639-3649.

47. Rossner S, Sastre M, Bourne K, Lichtenthaler SF: Transcriptional and translational regulation of BACE1 expression-implications for Alzheimer's disease. Prog Neurobiol 2006, 79:95-111.

48. Stockley JH, O'Neill C: Understanding BACE1: essential protease for amyloid-beta production in Alzheimer's disease. Cell Mol Life Sci 2008, 65:3265-3289

49. Wang JF, Lu R, Wang YZ: Regulation of beta cleavage of amyloid precursor protein. Neurosci Bull 2010, 26:417-427.

50. Tamagno E, Bardini P, Guglielmotto M, Danni O, Tabaton M: The various aggregation states of beta-amyloid 1-42 mediate different effects on oxidative stress, neurodegeneration, and BACE-1 expression. Free Radic Biol Med 2006, 41:202-212.

51. Tamagno E, Guglielmotto M, Aragno M, Borghi R, Autelli R, Giliberto L, Muraca G, Danni O, Zhu X, Smith MA, et al: Oxidative stress activates a positive feedback between the gamma- and beta-secretase cleavages of the beta-amyloid precursor protein. J Neurochem 2008, 104:683-695.

52. Buggia-Prevot V, Sevalle J, Rossner S, Checler F: NFkappaB-dependent control of BACE1 promoter transactivation by Abeta42. J Biol Chem 2008, 283:10037-10047.

53. Sadleir KR, Vassar R: Cdk5 protein inhibition and Abeta42 increase BACE1 protein level in primary neurons by a post-transcriptional mechanism: implications of CDK5 as a therapeutic target for Alzheimer disease. J Biol Chem 2012, 287:7224-7235.

54. Valko M, Leibfritz D, Moncol J, Cronin MT, Mazur M, Telser J: Free radicals and antioxidants in normal physiological functions and human disease. Int J Biochem Cell Biol 2007, 39:44-84.

55. Harman D: Free radicals in aging. Mol Cell Biochem 1988, 84:155-161.

56. Smith MA, Perry G, Richey PL, Sayre LM, Anderson VE, Beal MF, Kowall N: Oxidative damage in Alzheimer's. Nature 1996, 382:120-121.

57. Behl C, Moosmann B: Antioxidant neuroprotection in Alzheimer's disease as preventive and therapeutic approach. Free Radic Biol Med 2002, 33:182-191.

58. Guglielmotto M, Giliberto L, Tamagno E, Tabaton M: Oxidative stress mediates the pathogenic effect of different Alzheimer's disease risk factors. Front Aging Neurosci 2010, 2:3.

59. Sultana R, Butterfield DA: Role of Oxidative Stress in the Progression of Alzheimer's Disease. J Alzheimers Dis 2009

60. Butterfield DA, Abdul HM, Opii W, Newman SF, Joshi G, Ansari MA, Sultana R: Pin1 in Alzheimer's disease. J Neurochem 2006, 98:1697-1706.

61. Castellani RJ, Lee HG, Perry G, Smith MA: Antioxidant protection and neurodegenerative disease: the role of amyloid-beta and tau. Am J Alzheimers Dis Other Demen 2006, 21:126-130.

62. Huang X, Atwood CS, Hartshorn MA, Multhaup G, Goldstein LE, Scarpa RC, Cuajungco MP, Gray DN, Lim J, Moir RD, et al: The A beta peptide of Alzheimer's disease directly produces hydrogen peroxide through metal ion reduction. Biochemistry 1999, 38:7609-7616.

63. Huang X, Cuajungco MP, Atwood CS, Hartshorn MA, Tyndall JD, Hanson GR, Stokes KC, Leopold M, Multhaup G, Goldstein LE, et al: Cu(II) potentiation of alzheimer abeta neurotoxicity. Correlation with cell-free hydrogen peroxide production and metal reduction. J Biol Chem 1999 274:37111-37116.

64. Kim HC, Yamada K, Nitta A, Olariu A, Tran MH, Mizuno M, Nakajima A, Nagai T, Kamei $H$, Jhoo WK, et al: Immunocytochemical evidence that amyloid beta (1-42) impairs endogenous antioxidant systems in vivo. Neuroscience 2003, 119:399-419.

65. Borghi R, Patriarca S, Traverso N, Piccini A, Storace D, Garuti A, Gabriella C, Patrizio O, Massimo T: The increased activity of BACE1 correlates with oxidative stress in Alzheimer's disease. Neurobiol Aging 2007 28:1009-1014.

66. Tong Y, Zhou W, Fung V, Christensen MA, Qing H, Sun X, Song W: Oxidative stress potentiates BACE1 gene expression and Abeta generation. J Neural Transm 2005, 112:455-469.

67. Tamagno E, Bardini P, Obbili A, Vitali A, Borghi R, Zaccheo D, Pronzato MA, Danni O, Smith MA, Perry G, Tabaton M: Oxidative stress increases expression and activity of BACE in NT2 neurons. Neurobiol Dis 2002, 10:279-288.

68. Paola D, Domenicotti C, Nitti M, Vitali A, Borghi R, Cottalasso D, Zaccheo D, Odetti P, Strocchi P, Marinari UM, et al: Oxidative stress induces increase in intracellular amyloid beta-protein production and selective activation of betal and betall PKCs in NT2 cells. Biochem Biophys Res Commun 2000, 268:642-646.

69. Tamagno E, Parola M, Bardini P, Piccini A, Borghi R, Guglielmotto M, Santoro G, Davit A, Danni O, Smith MA, et al: Beta-site APP cleaving enzyme up-regulation induced by 4-hydroxynonenal is mediated by stressactivated protein kinases pathways. J Neurochem 2005, 92:628-636.

70. Mehan S, Meena H, Sharma D, Sankhla R: JNK: a stress-activated protein kinase therapeutic strategies and involvement in Alzheimer's and various neurodegenerative abnormalities. J Mol Neurosci 2011 43:376-390

71. Yao M, Nguyen TV, Pike CJ: Beta-amyloid-induced neuronal apoptosis involves $\mathrm{c}$-Jun $\mathrm{N}$-terminal kinase-dependent downregulation of $\mathrm{Bcl}-\mathrm{w}$. J Neurosci 2005, 25:1149-1158.

72. Guglielmotto M, Monteleone D, Giliberto L, Fornaro M, Borghi R, Tamagno E, Tabaton M: Amyloid-beta activates the expression of BACE1 through the JNK pathway. J Alzheimers Dis 2011, 27:871-883.

73. Zhu X, Raina AK, Rottkamp CA, Aliev G, Perry G, Boux H, Smith MA Activation and redistribution of $\mathrm{c}$-jun $\mathrm{N}$-terminal kinase/stress activated protein kinase in degenerating neurons in Alzheimer's disease. J Neurochem 2001, 76:435-441.

74. Tamagno E, Parola M, Guglielmotto M, Santoro G, Bardini P, Marra L, Tabaton M, Danni O: Multiple signaling events in amyloid beta-induced, oxidative stress-dependent neuronal apoptosis. Free Radic Biol Med 2003 35:45-58.

75. Sastre M, Klockgether T, Heneka MT: Contribution of inflammatory processes to Alzheimer's disease: molecular mechanisms. Int J Dev Neurosci 2006, 24:167-176.

76. Tuppo EE, Arias HR: The role of inflammation in Alzheimer's disease. Int J Biochem Cell Biol 2005, 37:289-305.

77. Lynch MA: Age-related neuroinflammatory changes negatively impact on neuronal function. Front Aging Neurosci 2010, 1:6.

78. Eikelenboom $\mathrm{P}$, Veerhuis $\mathrm{R}$ : The role of complement and activated microglia in the pathogenesis of Alzheimer's disease. Neurobiol Aging 1996, 17:673-680.

79. Akiyama H, Barger S, Barnum S, Bradt B, Bauer J, Cole GM, Cooper NR, Eikelenboom P, Emmerling M, Fiebich BL, et al: Inflammation and Alzheimer's disease. Neurobiol Aging 2000, 21:383-421.

80. Krause DL, Muller N: Neuroinflammation, microglia and implications for anti-inflammatory treatment in Alzheimer's disease. Int J Alzheimers Dis 2010.

81. Wyss-Coray T, Mucke L: Inflammation in neurodegenerative disease-a double-edged sword. Neuron 2002, 35:419-432.

82. Munch G, Gasic-Milenkovic J, Dukic-Stefanovic S, Kuhla B, Heinrich K, Riederer P, Huttunen HJ, Founds H, Sajithlal G: Microglial activation induces cell death, inhibits neurite outgrowth and causes neurite retraction of differentiated neuroblastoma cells. Exp Brain Res 2003, 150:1-8

83. Meda L, Cassatella MA, Szendrei Gl, Otvos L Jr, Baron P, Villalba M, Ferrari D, Rossi F: Activation of microglial cells by beta-amyloid protein and interferon-gamma. Nature 1995, 374:647-650. 
84. Johnstone M, Gearing AJ, Miller KM: A central role for astrocytes in the inflammatory response to beta-amyloid; chemokines, cytokines and reactive oxygen species are produced. J Neuroimmunol 1999, 93:182-193.

85. Bamberger ME, Harris ME, McDonald DR, Husemann J, Landreth GE: A cell surface receptor complex for fibrillar beta-amyloid mediates microglial activation. J Neurosci 2003, 23:2665-2674.

86. Yan SD, Chen X, Fu J, Chen M, Zhu H, Roher A, Slattery T, Zhao L, Nagashima M, Morser J, et al: RAGE and amyloid-beta peptide neurotoxicity in Alzheimer's disease. Nature 1996, 382:685-691.

87. Rogers J, Cooper NR, Webster S, Schultz J, McGeer PL, Styren SD, Civin WH, Brachova L, Bradt B, Ward P, et al: Complement activation by beta-amyloid in Alzheimer disease. Proc Natl Acad Sci USA 1992, 89:10016-10020.

88. Mercurio F, Manning AM: NF-kappaB as a primary regulator of the stress response. Oncogene 1999, 18:6163-6171.

89. Schreck R, Rieber P, Baeuerle PA: Reactive oxygen intermediates as apparently widely used messengers in the activation of the NF-kappa B transcription factor and HIV-1. EMBO J 1991, 10:2247-2258.

90. Clemens JA, Stephenson DT, Smalstig EB, Dixon EP, Little SP: Global ischemia activates nuclear factor-kappa $B$ in forebrain neurons of rats. Stroke 1997, 28:1073-1080. discussion 1080-1071.

91. Yang K, Mu XS, Hayes RL: Increased cortical nuclear factor-kappa B (NF-kappa B) DNA binding activity after traumatic brain injury in rats. Neurosci Lett 1995, 197:101-104.

92. Lawrence $\mathrm{T}$ : The nuclear factor NF-kappaB pathway in inflammation. Cold Spring Harb Perspect Biol 2009, 1:a001651.

93. Kaltschmidt B, Uherek M, Volk B, Baeuerle PA, Kaltschmidt C: Transcription factor NF-kappaB is activated in primary neurons by amyloid beta peptides and in neurons surrounding early plaques from patients with Alzheimer disease. Proc Natl Acad Sci USA 1997, 94:2642-2647.

94. Kaltschmidt B, Uherek M, Wellmann H, Volk B, Kaltschmidt C: Inhibition of NF-kappaB potentiates amyloid beta-mediated neuronal apoptosis. Proc Natl Acad Sci USA 1999, 96:9409-9414.

95. Terai K, Matsuo A, McGeer PL: Enhancement of immunoreactivity for NF-kappa B in the hippocampal formation and cerebral cortex of Alzheimer's disease. Brain Res 1996, 735:159-168.

96. Barger SW, Horster D, Furukawa K, Goodman Y, Krieglstein J, Mattson MP: Tumor necrosis factors alpha and beta protect neurons against amyloid beta-peptide toxicity: evidence for involvement of a kappa B-binding factor and attenuation of peroxide and $\mathrm{Ca} 2+$ accumulation. Proc Nat Acad Sci USA 1995, 92:9328-9332

97. Huang $X$, Chen $Y$, Zhang $H, M a ~ Q$, Zhang YW, Xu H: Salubrinal attenuates beta-amyloid-induced neuronal death and microglial activation by inhibition of the NF-kappaB pathway. Neurobiol Aging 2011.

98. Sheng JG, Bora SH, Xu G, Borchelt DR, Price DL, Koliatsos VE: Lipopolysaccharide-induced-neuroinflammation increases intracellular accumulation of amyloid precursor protein and amyloid beta peptide in APPswe transgenic mice. Neurobiol Dis 2003, 14:133-145.

99. Sambamurti K, Kinsey R, Maloney B, Ge YW, Lahiri DK: Gene structure and organization of the human beta-secretase (BACE) promoter. FASEB $J$ 2004, 18:1034-1036.

100. Chami L, Buggia-Prevot V, Duplan E, Delprete D, Chami M, Peyron JF, Checler F: Nuclear factor-kappa B regulates betaAPP and beta- and gamma-secretases differently at physiological and supraphysiological Abeta concentrations. J Biol Chem 2012, 287:24573-24584.

101. Sung S, Yang H, Uryu K, Lee EB, Zhao L, Shineman D, Trojanowski JQ, Lee VM, Pratico D: Modulation of nuclear factor-kappa B activity by indomethacin influences $A$ beta levels but not $A$ beta precursor protein metabolism in a model of Alzheimer's disease. Am J Pathol 2004, 165:2197-2206.

102. Paris D, Ganey NJ, Laporte V, Patel NS, Beaulieu-Abdelahad D, Bachmeier C, March A, Ait-Ghezala G, Mullan MJ: Reduction of beta-amyloid pathology by celastrol in a transgenic mouse model of Alzheimer's disease. J Neuroinflammation 2010, 7:17.

103. Choi DY, Lee JW, Lin G, Lee YK, Lee YH, Choi IS, Han SB, Jung JK, Kim YH, Kim KH, et al: Obovatol attenuates LPS-induced memory impairments in mice via inhibition of NF-kappaB signaling pathway. Neurochem Int 2011.

104. He P, Zhong Z, Lindholm K, Berning L, Lee W, Lemere C, Staufenbiel M, Li R, Shen $Y$ : Deletion of tumor necrosis factor death receptor inhibits amyloid beta generation and prevents learning and memory deficits in Alzheimer's mice. J Cell Biol 2007, 178:829-841.
105. Guglielmotto M, Aragno M, Tamagno E, Vercellinatto I, Visentin S, Medana C, Catalano MG, Smith MA, Perry G, Danni O, et al: AGEs/RAGE complex upregulates BACE1 via NF-kappaB pathway activation. Neurobiol Aging 2010, 33(196 e):113-127.

106. Heneka MT, Landreth GE: PPARs in the brain. Biochim Biophys Acta 2007, 1771:1031-1045

107. Sastre M, Dewachter I, Landreth GE, Willson TM, Klockgether T, van Leuven F, Heneka MT: Nonsteroidal anti-inflammatory drugs and peroxisome proliferator-activated receptor-gamma agonists modulate immunostimulated processing of amyloid precursor protein through regulation of beta-secretase. J Neurosci 2003, 23:9796-9804.

108. Heneka MT, Sastre M, Dumitrescu-Ozimek L, Hanke A, Dewachter I, Kuiperi C, O'Banion K, Klockgether T, Van Leuven F, Landreth GE: Acute treatment with the PPARgamma agonist pioglitazone and ibuprofen reduces glial inflammation and Abeta1-42 levels in APPV717I transgenic mice. Brain 2005, 128:1442-1453.

109. D'Abramo C, Massone S, Zingg JM, Pizzuti A, Marambaud P, Dalla Piccola B, Azzi A, Marinari UM, Pronzato MA, Ricciarelli R: Role of peroxisome proliferator-activated receptor gamma in amyloid precursor protein processing and amyloid beta-mediated cell death. Biochem J 2005, 391:693-698.

110. Gong B, Chen F, Pan Y, Arrieta-Cruz I, Yoshida Y, Haroutunian V, Pasinetti GM: SCF(Fbx2) -E3-ligase-mediated degradation of BACE1 attenuates Alzheimer's disease amyloidosis and improves synaptic function. Aging Cell 2010, 9:1018-1031.

111. Cho HJ, Kim SK, Jin SM, Hwang EM, Kim YS, Huh K, Mook-Jung I: IFNgamma-induced BACE1 expression is mediated by activation of JAK2 and ERK1/2 signaling pathways and direct binding of STAT1 to BACE1 promoter in astrocytes. Glia 2007, 55:253-262.

112. Zhao J, O'Connor T, Vassar R: The contribution of activated astrocytes to Abeta production: Implications for Alzheimer's disease pathogenesis. J Neuroinflammation 2011, 8:150.

113. Amara FM, Junaid A, Clough RR, Liang B: TGF-beta(1), regulation of alzheimer amyloid precursor protein mRNA expression in a normal human astrocyte cell line: mRNA stabilization. Brain Res Mol Brain Res 1999, 71:42-49.

114. Rogers JT, Leiter LM, McPhee J, Cahill CM, Zhan SS, Potter H, Nilsson LN: Translation of the alzheimer amyloid precursor protein mRNA is up-regulated by interleukin-1 through 5 '-untranslated region sequences. J Biol Chem 1999, 274:6421-6431.

115. Rossner S, Lange-Dohna C, Zeitschel U, Perez-Polo JR: Alzheimer's disease beta-secretase BACE1 is not a neuron-specific enzyme. J Neurochem 2005, 92:226-234

116. Hartlage-Rubsamen M, Zeitschel U, Apelt J, Gartner U, Franke H, Stahl T, Gunther A, Schliebs R, Penkowa M, Bigl V, Rossner S: Astrocytic expression of the Alzheimer's disease beta-secretase (BACE1) is stimulus-dependent. Glia 2003, 41:169-179.

117. Bettegazzi B, Mihailovich M, Di Cesare A, Consonni A, Macco R, Pelizzoni I, Codazzi F, Grohovaz F, Zacchetti D: beta-Secretase activity in rat astrocytes: translational block of BACE1 and modulation of BACE2 expression. Eur J Neurosci 2011.

118. Kihara T, Shimmyo Y, Akaike A, Niidome T, Sugimoto H: Abeta-induced BACE-1 cleaves N-terminal sequence of mPGES-2. Biochem Biophys Res Commun 2010, 393:728-733.

119. Berridge MJ, Bootman MD, Lipp P: Calcium-a life and death signal. Nature 1998, 395:645-648.

120. Small DH, Gasperini R, Vincent AJ, Hung AC, Foa L: The role of Abeta-induced calcium dysregulation in the pathogenesis of Alzheimer's disease. J Alzheimers Dis 2009, 16:225-233.

121. Berridge MJ: Calcium hypothesis of Alzheimer's disease. Pflugers Arch 2009, 459:441-449.

122. Bezprozvanny I, Mattson MP: Neuronal calcium mishandling and the pathogenesis of Alzheimer's disease. Trends Neurosci 2008, 31:454-463.

123. Gibson GE, Karuppagounder SS, Shi Q: Oxidant-induced changes in mitochondria and calcium dynamics in the pathophysiology of Alzheimer's disease. Ann N Y Acad Sci 2008, 1147:221-232.

124. Dreses-Werringloer U, Lambert JC, Vingtdeux V, Zhao H, Vais $H$, Siebert $A$, Jain A, Koppel J, Rovelet-Lecrux A, Hannequin D, et al: A polymorphism in CALHM1 influences Ca2+ homeostasis, Abeta levels, and Alzheimer's disease risk. Cell 2008, 133:1149-1161. 
125. Lambert JC, Sleegers K, Gonzalez-Perez A, Ingelsson M, Beecham GW, Hiltunen M, Combarros O, Bullido MJ, Brouwers N, Bettens K, et al: The CALHM1 P86L polymorphism is a genetic modifier of age at onset in Alzheimer's disease: a meta-analysis study. J Alzheimers Dis 2010, 22:247-255.

126. Alberdi E, Sanchez-Gomez MV, Cavaliere F, Perez-Samartin A, Zugaza JL, Trullas R, Domercq M, Matute C: Amyloid beta oligomers induce Ca2+ dysregulation and neuronal death through activation of ionotropic glutamate receptors. Cell Calcium 2010, 47:264-272.

127. Lin H, Bhatia R, Lal R: Amyloid beta protein forms ion channels: implications for Alzheimer's disease pathophysiology. FASEB J 2001, 15:2433-2444

128. Sepulveda FJ, Parodi J, Peoples RW, Opazo C, Aguayo LG: Synaptotoxicity of Alzheimer beta amyloid can be explained by its membrane perforating property. PLOS One 2010, 5:e11820.

129. Chan SL, Mayne M, Holden CP, Geiger JD, Mattson MP: Presenilin-1 mutations increase levels of ryanodine receptors and calcium release in PC12 cells and cortical neurons. J Biol Chem 2000, 275:18195-18200.

130. Cheung KH, Shineman D, Muller M, Cardenas C, Mei L, Yang J, Tomita T, Iwatsubo T, Lee VM, Foskett JK: Mechanism of Ca2+ disruption in Alzheimer's disease by presenilin regulation of InsP3 receptor channel gating. Neuron 2008, 58:871-883.

131. Green KN, Demuro A, Akbari Y, Hitt BD, Smith IF, Parker I, LaFerla FM: SERCA pump activity is physiologically regulated by presenilin and regulates amyloid beta production. J Cell Biol 2008, 181:1107-1116.

132. Oulès B, Del Prete $D$, Greco B, Zhang $X$, Lauritzen I, Sevalle J, Moreno S, Paterlini-Bréchot $P$, Trebak $M$, Checler $F$, et al: Ryanodine receptors blockade reduces Amyloid-beta load and memory impairments in Tg2576 mouse model of Alzheimer disease. J Neurosci 2012, 32:11820-11834.

133. Cao X, Sudhof TC: A transcriptionally [correction of transcriptively] active complex of APP with Fe65 and histone acetyltransferase Tip60. Science 2001, 293:115-120.

134. Muller $T$, Meyer $H E$, Egensperger R, Marcus $K$ : The amyloid precursor protein intracellular domain (AICD) as modulator of gene expression, apoptosis, and cytoskeletal dynamics-relevance for Alzheimer's disease. Prog Neurobiol 2008, 85:393-406.

135. Pardossi-Piquard R, Checler F: The physiology of the beta-amyloid precursor protein intracellular domain AICD. J Neurochem 2012, 120(Suppl 1):109-124.

136. Leissring MA, Murphy MP, Mead TR, Akbari Y, Sugarman MC, Jannatipour M, Anliker B, Muller U, Saftig P, De Strooper B, et al: A physiologic signaling role for the gamma -secretase-derived intracellular fragment of APP. Proc Natl Acad Sci USA 2002, 99:4697-4702.

137. Hamid R, Kilger E, Willem M, Vassallo N, Kostka M, Bornhovd C, Reichert AS, Kretzschmar HA, Haass C, Herms J: Amyloid precursor protein intracellular domain modulates cellular calcium homeostasis and ATP content. J Neurochem 2007, 102:1264-1275.

138. Querfurth HW, Selkoe DJ: Calcium ionophore increases amyloid beta peptide production by cultured cells. Biochemistry 1994, 33:4550-4561.

139. Pierrot N, Santos SF, Feyt C, Morel M, Brion JP, Octave JN: Calciummediated transient phosphorylation of tau and amyloid precursor protein followed by intraneuronal amyloid-beta accumulation. J Biol Chem 2006, 281:39907-39914

140. Mattson MP: Antigenic changes similar to those seen in neurofibrillary tangles are elicited by glutamate and $\mathrm{Ca} 2+$ influx in cultured hippocampal neurons. Neuron 1990, 4:105-117.

141. Higuchi M, Iwata N, Matsuba Y, Takano J, Suemoto T, Maeda J, Ji B, Ono M, Staufenbiel M, Suhara T, Saido TC: Mechanistic involvement of the calpain-calpastatin system in Alzheimer neuropathology. FASEB J 2012 26:1204-1217

142. Liu F, Grundke-labal I, Iqbal K, Oda Y, Tomizawa K, Gong CX: Truncation and activation of calcineurin $A$ by calpain I in Alzheimer disease brain. J Biol Chem 2005, 280:37755-37762.

143. Liang B, Duan BY, Zhou XP, Gong JX, Luo ZG: Calpain activation promotes BACE1 expression, amyloid precursor protein processing, and amyloid plaque formation in a transgenic mouse model of Alzheimer disease. J Biol Chem 2010, 285:27737-27744.

144. Kusakawa G, Saito T, Onuki R, Ishiguro K, Kishimoto T, Hisanaga S: Calpain-dependent proteolytic cleavage of the p35 cyclin-dependent kinase 5 activator to p25. J Biol Chem 2000,

275:17166-17172.
145. Cho HJ, Jin SM, Youn HD, Huh K, Mook-Jung I: Disrupted intracellular calcium regulates BACE1 gene expression via nuclear factor of activated T cells 1 (NFAT 1) signaling. Aging Cell 2008, 7:137-147.

146. Hayley M, Perspicace S, Schulthess T, Seelig J: Calcium enhances the proteolytic activity of BACE1: An in vitro biophysical and biochemical characterization of the BACE1-calcium interaction. Biochim Biophys Acta 2009, 1788:1933-1938.

147. Buxbaum JD, Ruefli AA, Parker CA, Cypess AM, Greengard P: Calcium regulates processing of the Alzheimer amyloid protein precursor in a protein kinase Cindependent manner. Proc Natl Acad Sci USA 1994, 91:4489-4493.

148. Lee MS, Kwon YT, Li M, Peng J, Friedlander RM, Tsai LH: Neurotoxicity induces cleavage of p35 to p25 by calpain. Nature 2000, 405:360-364.

149. Munch G, Thome J, Foley P, Schinzel R, Riederer P: Advanced glycation endproducts in ageing and Alzheimer's disease. Brain Res Brain Res Rev 1997, 23:134-143.

150. Li JJ, Surini M, Catsicas S, Kawashima E, Bouras C: Age-dependent accumulation of advanced glycosylation end products in human neurons. Neurobiol Aging 1995, 16:69-76.

151. Ramasamy R, Yan SF, Schmidt AM: Advanced glycation endproducts: from precursors to RAGE: round and round we go. Amino Acids 2010.

152. Neeper M, Schmidt AM, Brett J, Yan SD, Wang F, Pan YC, Elliston K, Stern D, Shaw A: Cloning and expression of a cell surface receptor for advanced glycosylation end products of proteins. J Biol Chem 1992, 267:14998-15004.

153. Yan SD, Yan SF, Chen X, Fu J, Chen M, Kuppusamy P, Smith MA, Perry G, Godman GC, Nawroth P, et al: Non-enzymatically glycated tau in Alzheimer's disease induces neuronal oxidant stress resulting in cytokine gene expression and release of amyloid beta-peptide. Nat Med 1995, 1:693-699.

154. Neumann A, Schinzel R, Palm D, Riederer P, Munch G: High molecular weight hyaluronic acid inhibits advanced glycation endproduct-induced NF-kappaB activation and cytokine expression. FEBS Lett 1999, 453:283-287.

155. Li J, Schmidt AM: Characterization and functional analysis of the promoter of RAGE, the receptor for advanced glycation end products. J Biol Chem 1997, 272:16498-16506.

156. Smith MA, Taneda S, Richey PL, Miyata S, Yan SD, Stern D, Sayre LM, Monnier VM, Perry G: Advanced Maillard reaction end products are associated with Alzheimer disease pathology. Proc Natl Acad Sci USA 1994, 91:5710-5714.

157. Vitek MP, Bhattacharya K, Glendening JM, Stopa E, Vlassara H, Bucala R, Manogue K, Cerami A: Advanced glycation end products contribute to amyloidosis in Alzheimer disease. Proc Natl Acad Sci USA 1994, 91:4766-4770.

158. Yan SD, Chen X, Schmidt AM, Brett J, Godman G, Zou YS, Scott CW, Caputo C, Frappier T, Smith MA, et al: Glycated tau protein in Alzheimer disease: a mechanism for induction of oxidant stress. Proc Natl Acad Sci USA 1994, 91:7787-7791.

159. Dickson DW, Sinicropi S, Yen SH, Ko LW, Mattiace LA, Bucala R, Vlassara H: Glycation and microglial reaction in lesions of Alzheimer's disease. Neurobiol Aging 1996, 17:733-743.

160. Ledesma MD, Bonay P, Colaco C, Avila J: Analysis of microtubuleassociated protein tau glycation in paired helical filaments. $J$ Biol Chem 1994, 269:21614-21619.

161. Munch G, Mayer S, Michaelis J, Hipkiss AR, Riederer P, Muller R, Neumann A, Schinzel R, Cunningham AM: Influence of advanced glycation endproducts and AGE-inhibitors on nucleation-dependent polymerization of beta-amyloid peptide. Biochim Biophys Acta 1997, 1360:17-29.

162. Lue LF, Walker DG, Brachova L, Beach TG, Rogers J, Schmidt AM, Stern DM, Yan SD: Involvement of microglial receptor for advanced glycation endproducts (RAGE) in Alzheimer's disease: identification of a cellular activation mechanism. Exp Neurol 2001, 171:29-45.

163. Arancio O, Zhang HP, Chen X, Lin C, Trinchese F, Puzzo D, Liu S, Hegde A, Yan SF, Stern A, et al: RAGE potentiates Abeta-induced perturbation of neuronal function in transgenic mice. EMBO J 2004, 23:4096-4105.

164. Ko SY, Lin YP, Lin YS, Chang SS: Advanced glycation end products enhance amyloid precursor protein expression by inducing reactive oxygen species. Free Radic Biol Med 2010, 49:474-480.

165. Cho HJ, Son SM, Jin SM, Hong HS, Shin DH, Kim SJ, Huh K, Mook-Jung I: RAGE regulates BACE1 and Abeta generation via NFAT1 activation in Alzheimer's disease animal model. FASEB J 2009, 23:2639-2649. 
166. Guglielmotto M, Aragno M, Tamagno E, Vercellinatto I, Visentin S, Medana C, Catalano MG, Smith MA, Perry G, Danni O, et al: AGEs/RAGE complex upregulates BACE1 via NF-kappaB pathway activation. Neurobiol Aging 2012, 33:196.e13-27.

167. Jellinger KA, Paulus W, Wrocklage C, Litvan I: Effects of closed traumatic brain injury and genetic factors on the development of Alzheimer's disease. Eur J Neurol 2001, 8:707-710.

168. Roberts GW, Gentleman SM, Lynch A, Graham Dl: beta A4 amyloid protein deposition in brain after head trauma. Lancet 1991, 338:1422-1423.

169. Uryu K, Laurer H, Mclntosh T, Pratico D, Martinez D, Leight S, Lee VM, Trojanowski JQ: Repetitive mild brain trauma accelerates Abeta deposition, lipid peroxidation, and cognitive impairment in a transgenic mouse model of Alzheimer amyloidosis. J Neurosci 2002, 22:446-454.

170. Blasko I, Beer R, Bigl M, Apelt J, Franz G, Rudzki D, Ransmayr G, Kampfl A Schliebs R: Experimental traumatic brain injury in rats stimulates the expression, production and activity of Alzheimer's disease beta-secretase (BACE-1). J Neural Transm 2004, 111:523-536.

171. Chen XH, Siman R, Iwata A, Meaney DF, Trojanowski JQ, Smith DH: Long-term accumulation of amyloid-beta, beta-secretase, presenilin-1, and caspase- 3 in damaged axons following brain trauma. Am J Pathol 2004, 165:357-371

172. Loane DJ, Pocivavsek A, Moussa CE, Thompson R, Matsuoka Y, Faden Al, Rebeck GW, Burns MP: Amyloid precursor protein secretases as therapeutic targets for traumatic brain injury. Nat Med 2009, 15:377-379.

173. Sanz O, Acarin L, Gonzalez B, Castellano B: NF-kappaB and IkappaBalpha expression following traumatic brain injury to the immature rat brain. J Neurosci Res 2002, 67:772-780.

174. von Arnim CA, Tangredi MM, Peltan ID, Lee BM, Irizarry MC, Kinoshita A, Hyman BT: Demonstration of BACE (beta-secretase) phosphorylation and its interaction with GGA1 in cells by fluorescence-lifetime imaging microscopy. J Cell Sci 2004, 117:5437-5445.

175. He X, Li F, Chang WP, Tang J: GGA proteins mediate the recycling pathway of memapsin 2 (BACE). J Biol Chem 2005, 280:11696-11703.

176. Wahle T, Prager K, Raffler N, Haass C, Famulok M, Walter J: GGA proteins regulate retrograde transport of BACE1 from endosomes to the transGolgi network. Mol Cell Neurosci 2005, 29:453-461.

177. Walker KR, Kang EL, Whalen MJ, Shen Y, Tesco G: Depletion of GGA1 and GGA3 Mediates Postinjury Elevation of BACE1. J Neurosci 2012, 32:10423-10437

178. Rocchi A, Orsucci D, Tognoni G, Ceravolo R, Siciliano G: The role of vascular factors in late-onset sporadic Alzheimer's disease. Genetic and molecular aspects. Curr Alzheimer Res 2009, 6:224-237.

179. de la Torre JC: Pathophysiology of neuronal energy crisis in Alzheimer's disease. Neurodegener Dis 2008, 5:126-132.

180. Koistinaho M, Koistinaho J: Interactions between Alzheimer's disease and cerebral ischemia-focus on inflammation. Brain Res Brain Res Rev 2005, 48:240-250.

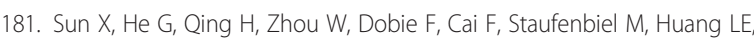
Song W: Hypoxia facilitates Alzheimer's disease pathogenesis by up-regulating BACE1 gene expression. Proc Natl Acad Sci USA 2006, 103:18727-18732

182. Guglielmotto M, Aragno M, Autelli R, Giliberto L, Novo E, Colombatto S, Danni O, Parola M, Smith MA, Perry G, et al: The up-regulation of BACE1 mediated by hypoxia and ischemic injury: role of oxidative stress and HIF1alpha. J Neurochem 2009, 108:1045-1056.

183. Bartus RT, Elliott PJ, Hayward NJ, Dean RL, Harbeson S, Straub JA, Li Z, Powers JC: Calpain as a novel target for treating acute neurodegenerative disorders. Neurol Res 1995, 17:249-258.

184. Wang J, Liu S, Fu Y, Wang JH, Lu Y: Cdk5 activation induces hippocampal CA1 cell death by directly phosphorylating NMDA receptors. Nat Neurosci 2003, 6:1039-1047

185. Wen Y, Yang SH, Liu R, Perez EJ, Brun-Zinkernagel AM, Koulen P, Simpkins $\mathrm{JW}$ : Cdk5 is involved in NFT-like tauopathy induced by transient cerebral ischemia in female rats. Biochim Biophys Acta 2007, 1772:473-483.

186. Zhai DX, Kong QF, Xu WS, Bai SS, Peng HS, Zhao K, Li GZ, Wang DD, Sun B, Wang $\mathrm{JH}$, et al: RAGE expression is up-regulated in human cerebral ischemia and pMCAO rats. Neurosci Lett 2008, 445:117-121.

187. Pichiule P, Chavez JC, Schmidt AM, Vannucci SJ: Hypoxia-inducible factor-1 mediates neuronal expression of the receptor for advanced glycation end products following hypoxia/ischemia. J Biol Chem 2007, 282: $36330-36340$
188. Taylor CT: Interdependent roles for hypoxia inducible factor and nuclear factor-kappaB in hypoxic inflammation. J Physiol 2008, 586:4055-4059.

189. Taylor CT, Cummins EP: The role of NF-kappaB in hypoxia-induced gene expression. Ann N Y Acad Sci 2009, 1177:178-184.

190. O'Connor T, Sadleir KR, Maus E, Velliquette RA, Zhao J, Cole SL, Eimer WA, Hitt B, Bembinster LA, Lammich $S$, et al: Phosphorylation of the translation initiation factor elF2alpha increases BACE1 levels and promotes amyloidogenesis. Neuron 2008, 60:988-1009.

191. Tesco G, Koh YH, Kang EL, Cameron AN, Das S, Sena-Esteves M, Hiltunen M, Yang SH, Zhong Z, Shen Y, et al: Depletion of GGA3 stabilizes BACE and enhances beta-secretase activity. Neuron 2007, 54:721-737.

192. Ohyagi Y, Asahara H, Chui DH, Tsuruta Y, Sakae N, Miyoshi K, Yamada T, Kikuchi $H$, Taniwaki T, Murai $H$, et al: Intracellular Abeta42 activates p53 promoter: a pathway to neurodegeneration in Alzheimer's disease. FASEB J 2005, 19:255-257.

193. Kitamura Y, Shimohama S, Kamoshima W, Matsuoka Y, Nomura Y, Taniguchi $\mathrm{T}$ : Changes of p53 in the brains of patients with Alzheimer's disease. Biochem Biophys Res Commun 1997, 232:418-421.

194. Checler F, Sunyach C, Pardossi-Piquard R, Sevalle J, Vincent B, Kawarai T, Girardot N, St George-Hyslop P, da Costa CA: The gamma/epsilonsecretase-derived APP intracellular domain fragments regulate p53. Curr Alzheimer Res 2007, 4:423-426.

195. Alves da Costa C, Paitel E, Mattson MP, Amson R, Telerman A, Ancolio K, Checler F: Wild-type and mutated presenilins 2 trigger p53-dependent apoptosis and down-regulate presenilin 1 expression in HEK293 human cells and in murine neurons. Proc Natl Acad Sci USA 2002, 99:4043-4048.

196. Alves da Costa C, Sunyach C, Pardossi-Piquard R, Sevalle J, Vincent B, Boyer N, Kawarai T, Girardot N, St George-Hyslop P, Checler F: Presenilindependent gamma-secretase-mediated control of p53-associated cell death in Alzheimer's disease. J Neurosci 2006, 26:6377-6385.

197. Dunys J, Sevalle J, Giaime E, Pardossi-Piquard R, Vitek MP, Renbaum P, LevyLahad E, Zhang YW, Xu H, Checler F, da Costa CA: p53-dependent control of transactivation of the Pen2 promoter by presenilins. J Cell Sci 2009, 122:4003-4008.

198. Checler F, Dunys J, Pardossi-Piquard R, Alves da Costa C: p53 is regulated by and regulates members of the gamma-secretase complex. Neurodegener Dis 2010, 7:50-55.

199. Hunter S, Friedland RP, Brayne C: Time for a change in the research paradigm for Alzheimer's disease: the value of a chaotic matrix modeling approach. CNS Neurosci Ther 2010, 16:254-262.

200. Ramsden M, Plant LD, Webster NJ, Vaughan PF, Henderson Z, Pearson HA: Differential effects of unaggregated and aggregated amyloid beta protein (1-40) on $\mathrm{K}(+)$ channel currents in primary cultures of rat cerebellar granule and cortical neurones. J Neurochem 2001, 79:699-712.

201. Plant LD, Boyle JP, Smith IF, Peers C, Pearson HA: The production of amyloid beta peptide is a critical requirement for the viability of central neurons. J Neurosci 2003, 23:5531-5535.

202. Giuffrida ML, Caraci F, Pignataro B, Cataldo S, De Bona P, Bruno V, Molinaro G, Pappalardo G, Messina A, Palmigiano A, et al: Beta-amyloid monomers are neuroprotective. J Neurosci 2009, 29:10582-10587.

203. Baba A, Mitsumori K, Yamada MK, Nishiyama N, Matsuki N, Ikegaya Y: Beta-amyloid prevents excitotoxicity via recruitment of glial glutamate transporters. Naunyn Schmiedebergs Arch Pharmacol 2003, 368:234-238.

204. Nunomura A, Perry G, Aliev G, Hirai K, Takeda A, Balraj EK, Jones PK, Ghanbari H, Wataya T, Shimohama S, et al: Oxidative damage is the earliest event in Alzheimer disease. J Neuropathol Exp Neurol 2001, 60:759-767.

205. Zou K, Gong JS, Yanagisawa K, Michikawa M: A novel function of monomeric amyloid beta-protein serving as an antioxidant molecule against metal-induced oxidative damage. J Neurosci 2002, 22:4833-4841.

206. Atwood CS, Obrenovich ME, Liu T, Chan H, Perry G, Smith MA, Martins RN: Amyloid-beta: a chameleon walking in two worlds: a review of the trophic and toxic properties of amyloid-beta. Brain Res Brain Res Rev 2003, 43:1-16.

207. Lee HG, Casadesus G, Zhu X, Takeda A, Perry G, Smith MA: Challenging the amyloid cascade hypothesis: senile plaques and amyloid-beta as protective adaptations to Alzheimer disease. Ann N Y Acad Sci 2004, 1019:1-4.

208. Armstrong RA: The pathogenesis of Alzheimer's disease: a reevaluation of the "amyloid cascade hypothesis". Int J Alzheimers Dis 2011, 2011:630865. 
209. Chen Y, Huang X, Zhang YW, Rockenstein E, Bu G, Golde TE, Masliah E, Xu H: Alzheimer's beta-Secretase (BACE1) Regulates the CAMP/PKA/CREB Pathway Independently of beta-Amyloid. J Neurosci 2012, 32:11390-11395.

210. Luo X, Yan R: Inhibition of BACE1 for therapeutic use in Alzheimer's disease. Int J Clin Exp Pathol 2010, 3:618-628.

211. Frautschy SA, Cole GM: Why pleiotropic interventions are needed for Alzheimer's disease. Mol Neurobiol 2010, 41:392-409.

212. Jaturapatporn D, Isaac MG, McCleery J, Tabet N: Aspirin, steroidal and non-steroidal anti-inflammatory drugs for the treatment of Alzheimer's disease. Cochrane Database Syst Rev 2012, 2:CD006378.

doi:10.1186/1750-1326-7-52

Cite this article as: Chami and Checler: BACE1 is at the crossroad of a toxic vicious cycle involving cellular stress and $\beta$-amyloid production in Alzheimer's disease. Molecular Neurodegeneration 2012 7:52.

\section{Submit your next manuscript to BioMed Central and take full advantage of:}

- Convenient online submission

- Thorough peer review

- No space constraints or color figure charges

- Immediate publication on acceptance

- Inclusion in PubMed, CAS, Scopus and Google Scholar

- Research which is freely available for redistribution 